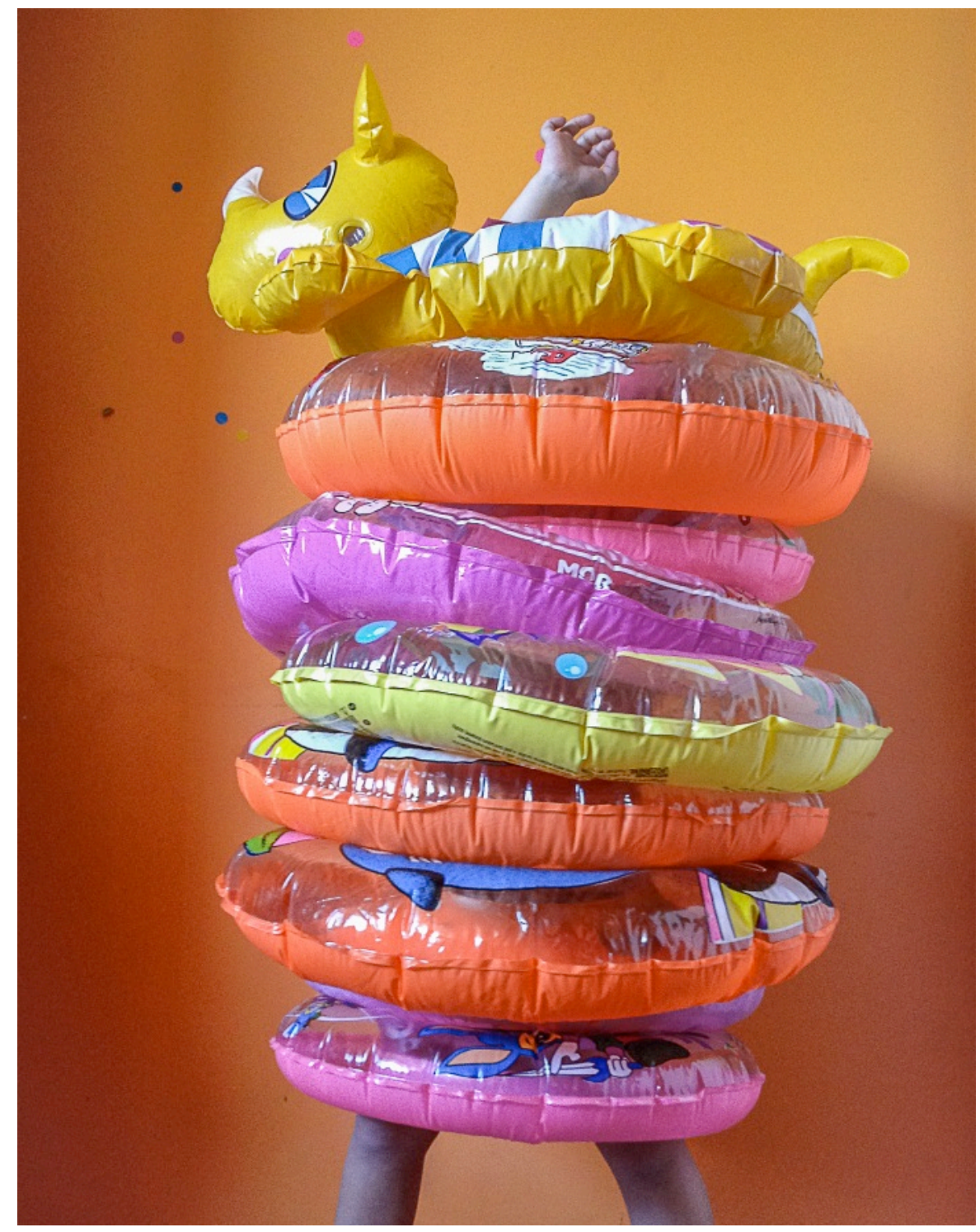

\title{
MANUAL SUPERFICIALÍSSIMO
}

de como as coisas podem ser criadas do nada e outros conceitos des-alfabéticos

Natasha de Albuquerque 
Agradeço à Bia Medeiros, ao Corpos

Informáticos, à Luisa Günther e aos corpos abertos à experimentação.

Dancemos juntxs.
Somos os propositores: somos o molde; a vocês cabe o sopro, no interior desse molde: o sentido de nossa existência.

Somos os propositores: nossa proposição é o diálogo. Sós não existimos; estamos a vosso dispor.

Somos os propositores: enterramos a obra de arte como tal e solicitamos a vocês para que o pensamento viva pela ação.

Somos os propositores: não lhes propomos nem o passado nem o futuro, mas o agora

(CLARK, 1980, p. 31) 


\section{INTRODUÇÃO}

Esta escrita começa na busca do outro: busca de preenchimento de um vazio entre eu e outro. Isso foi necessário a partir de uma percepção do espaço que é a paisagem de Brasília: espaços vazios, muitas vezes abandonados, em que poucas pessoas estão presentes ao mesmo tempo e há sensação de pouca troca. Me dá perplexidade passar por alguém depois de atravessar um deserto e, mesmo assim, a relação entre eu e outro ser de inexistência, fingir que o outro não existe, não haver um 'bom dia' que seja. Quem sabe: medo? Tudo isto alimenta uma percepção de se estar perto e ser distante.

\section{COMEÇO A FAZER UMA PRÁTiCA para aproximações.}

(sobre uma suposta ordem das coisas)

\author{
INTRODUÇÃO \\ OFICINA DE NIILISMO \\ MODALIDADES \\ MÉTODO \\ DESLIZAMENTO \\ (in)CONCLUSÃO \\ LISTA DE IMAGENS \\ REFERÊNCIAS BIBLIOGRÁFICAS
}

Um dos meus primeiros trabalhos, nunca teve registro fotográfico. Foi em 2010. Eu simplesmente pegava um batom, passava na boca e beijava o rosto de todos que estavam em volta. Gerava, assim, uma ligação visual entre as pessoas em um mesmo lugar por conta da cor do batom e deste batom registrar/evidenciar um

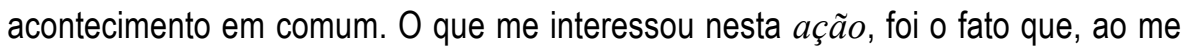
aproximar de uma pessoa conhecida ou desconhecida, eram geradas reações diferentes que não podiam ser previstas. Muita gente me agradeceu. Muita gente quis me agredir. Alguns levaram na malicia. Outros, na inocência. Muita gente se emocionou ou não reagiu. 0 que passou a me acompanhar, desde essa ação, é o prazer em testar a lida com os diferentes tipos de reações, o trato com a surpresa. 
O desconhecido passou a ser potencial da obra: desvenda (des-venda), multiplica e engendra. $O$ termo que eu uso é tanto faz se é performance ou não, porque o tipo de ação que faço não necessariamente é performance. 0 que interessa é o ATRAVESSAMENTO: o atravessamento do eu com outro; do eu com o outro em um espaço vazio que se preenche e que também atravessa para ser encontrado. Também me interesso pelo atravessamento das linguagens em que não dá para dizer se aquilo é simplesmente um vídeo; uma composição urbana; uma performance; instalação ou fotografia.

A questão não é a classificação, mas o desvio, para além do tangente das linguagens artísticas. $O$ que busco é algo que cruze vários aspectos: que se multiplique, que se acumule. Ao refazer e dar outros caminhos ao que seria/ou poderia ser a obra, espero o desvio do que espero: o que me importa é a surpresa da criação inesperada e da reação desconhecida.

Também quero desviar das expectativas.

A partir desta busca, em 2012, me deparo com o conceito de iteração e sua prática ao ingressar no Grupo de Pesquisa Corpos Informáticos (GPCl) articulado por Bia Medeiros, desde 1992. Me contamino com o Corpos e também sugiro proposições. É na iteração que está a potência da obra, a capacidade dela se multiplicar, de ser traduzida, interpretada, refeita e até traída. Refazer e dar outros caminhos, desviar do que esperamos: o que importa é a surpresa da criação inesperada, da reação desconhecida. 0 prazer do junto que desdobra no outro.
A criação, aqui, é entendida como espaço: espaço em branco que pode ser preenchido. Diferente do que é indicado ${ }^{1}$ por Deleuze (2007). Ou não tão diferente assim. Posso pensar esse espaço como uma sugestão de ideias, como uma palavra que não é propriamente determinada. Assim, entre o vazio e 0 outro, a interpretação pode levar a vários caminhos. Marcel Duchamp (2004) explica que na criação artística há uma falha do artista em expressar integralmente sua intenção, há também o que é expresso na obra não intencionalmente. 0 coeficiente de arte seria o vazio entre esses dois, o que uma obra de arte vem a ser inesperadamente, sua capacidade de transformação interpretativa, sua subjetividade. Duchamp relaciona esse vazio à transparência do objeto. Aqui, incluo esta transparência em bóias, nilismos e até nudismos.

Neste espaço aberto há possibilidade de mais criações e de sugestões para que aquele algo possa ser desvendado, modificado e também, traído. A questão está nas possibilidades que podem ser. É possível criar esse espaço vazio a partir do lançamento de uma dúvida? Dúvida se aquele algo significa isso ou aquilo, dúvida sobre a proposta, sobre como agir e também dúvida se isso é arte ou não. Voltamos ao termo: tanto faz se é performance ou não. E por que não seria? Performance?

1 Refiro-me à esta passagem: "É um erro acreditar que o pintor esteja diante de
uma superfície em branco. A crença figurativa decorre desse erro. Com efeito, se o
pintor estivesse diante de uma superfície em branco, poderia reproduzir nela um
objeto exterior que funcionaria como modelo. Mas não é isso o que acontece. O
pintor tem várias coisas na cabeça, ao seu redor ou no ateliê. Ora, tudo o que ele
tem na cabeça ou ao seu redor já está na tela, mais ou menos virtualmente, mais ou
menos atualmente, antes que ele comece o trabalho" (DELEUZE, 2007, p.91). 66 
A performance tem ligação com a vida e 0 cotidiano. A arte também pode ter. A performance é uma linguagem com a qual me identifico, mas não completamente; porque além de me interessar em atravessar outras linguagens, há o entendimento que performance é arte. Não sei se isto é bom ou ruim. 0 que incomoda é que a partir do momento que se pensa arte, em geral, chegamos em um lugar em que comumente não é permitido tocar e não se pode participar por um respeito à autoria do artista, respeito à obra 'pronta', respeito ao essencial da arte, à arte pura, como cita Arthur Danto (2006) a partir da visão de Clement Greenberg.

O termo tanto faz se é performance ou não assignifica o trabalho como arte e the dá um tratamento desimportante (sic!). Tal desimportância (sic!) é fundamental porque disto surge a liberdade do iterator para participar despretensiosamente. 0 que percebo é que pela despretensão da proposta e pelo abandono do valor, as pessoas se dão a liberdade de participar. Nessa criação, ou nessa reação acontece de tudo: banalidades, boas ideias, mal-gosto. A obra sai do controle. Essa mistura multiplica as possibilidades de desvendar a obra ou da arte ser outra coisa.

É na ligação com outro (ou outras, outros) que crio novas possibilidades. Entendo isso como uma troca: lanço uma ideia; o outro reage ou não; reajo à reação do outro. Estes laços e lances tornam a ação mais complexa e incompleta. Digo incompleta porque a ação nunca termina, ela só termina quando se abandona, se cansa, desiste. É bom que a ação esteja incompleta para que ela se preencha, como dizia Duchamp com o coeficiente de arte. 0 que quero dizer é que

qualquer coisa pode ser muita coisa.

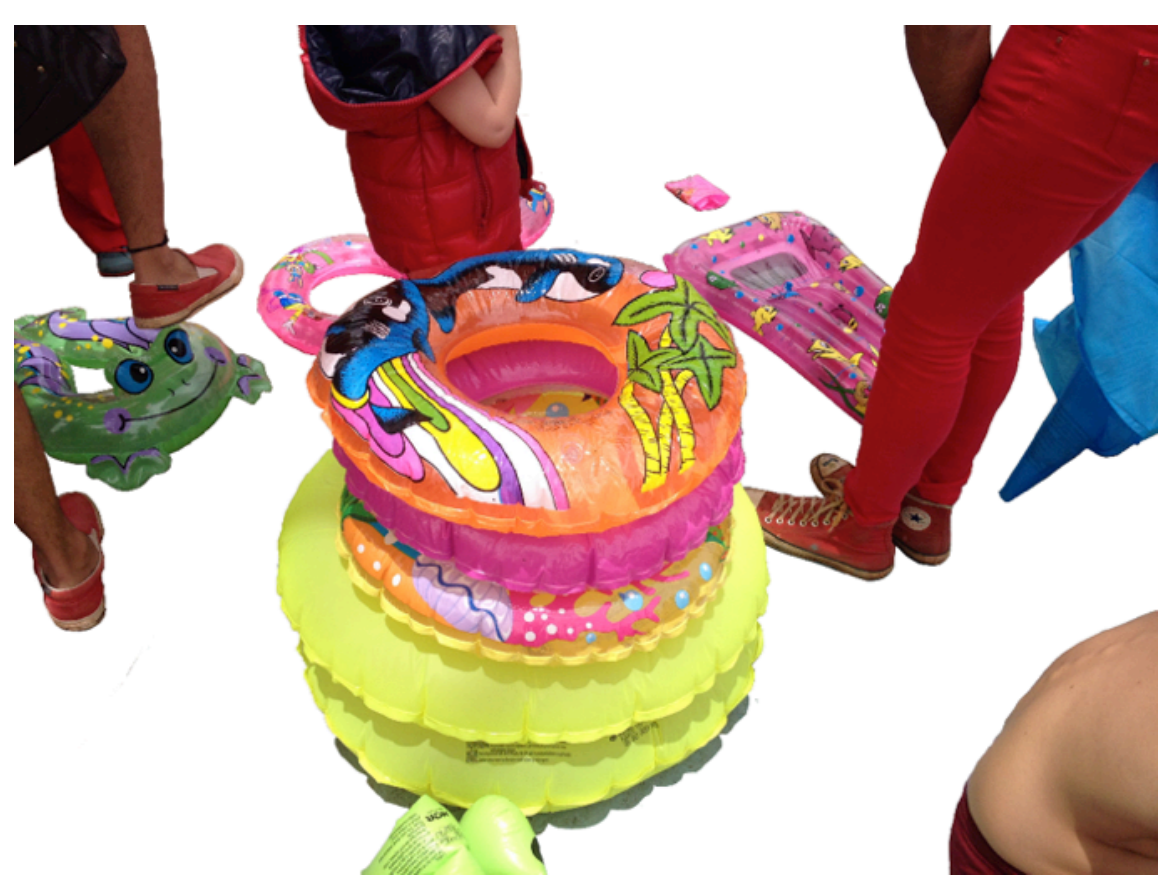




\section{OFICINA DE NiiLISMO}

A ação consiste numa oficina de nadar no nada.

(...) ou seja, nada de aprofundamentos epistemológicos, apenas superficialidades. Serão distribuídas boias de diferentes cores, formas e funcionalidades. Os participantes poderão encher as boias enquanto acontece a explicação teórica num pequeno quadro negro.

Tô boiando: gíria utilizada pelos brasilienses em momentos incompreensiveis, ou em momentos em que não se sabe 0 que está sendo dito e não há grandes esforços para entender. Bastante frequente em salas de aula. A sensação de estar boiando pode ser vista por terceiros como uma expressão de "cara de paisagem" em que se olha, mas não se vê.

Método Scanning: modelo de apreensão visual proposto por Joseph Beuys. Consiste em sentir o próprio corpo em continuidade com a paisagem; estender suas linhas à linha infinita do horizonte. Muito utilizado por Beuys para requalificar a relação do humano com o espaço aberto e afagar as visões descontínuas e fragmentadas da cidade grande. Para esta oficina, o Método Scanning é sugerido para o deslizamento nas superfícies da paisagem (a paisagem como qualquer coisa em totalidade, imensidão. Ou uma colher do ponto de vista de uma formiga ou de um ser humano que imagina).
$O$ ato de boiar também é proposto em ar e em olhar:

corpo que boia no vento, olhar que não vê e se torna paisagem.

Deriva: prática teorizada pelo situacionista Guy Debord que consiste em seguir um caminho não necessariamente óbvio, mas que se deixa levar pelo desejo e pelos sentidos. Guy Debord também teoriza a prática da Psicogeografia para análise do local. No caso, ficaremos com a parte de boas do Debord para contemplar o se perder e não necessariamente o saber. 0 que nos leva no acaso e descaso também faz parte da deriva -não é necessário um destino.

\section{MODALIDADES DA OFICINA DE NïLISMO}

1. Nado ou nada sincronizado: aglomeração de nadadores no nada.

2. Nádegas a declarar: nado onde as nádegas estão em evidência.

3. Balé de boias: as boias circulares são utilizadas como tutu de balé e os outros modelos como ajudantes da flutuação dos bailarinos.

Esta modalidade também dialoga com a modalidade 1.

4.

5.

6. $\operatorname{Nad}(x)$ : relativo à falta de distinções do ato de boiar.

7.

8. 


\section{MÉTODO}

A metodologia é usada aqui a partir do 'como'. Pode ser no sentido de 'poder ser' como também no sentido de 'comer'. Entre outros. Para isso, Corpos Informáticos propõe o Met-TODO na busca de potência poética para a totalidade do corpo. Ou como antropofagia do Método Scanning teorizado por Beuys. Ou também como deboche à imposições de métodos de performance. Como? Comer e viajar são os quatro princípios. A partir da etimologia ' $m e t$ ' (leia-se mete; de meter), buscamos o seu avesso, seu erro e a decadência da meta. Qual seria a meta?

Metáfora: duas palavras podem ser trocadas na mesma semântica.

Metonímia: ênfase a (a)comunicação substituindo uma palavra por outra.

Met-mínima: Percepção mínima do espaço. Um dedo enfiado, apenas. Não dar a mínima ao que lhe é concebido.

O quadro negro é pintado de branco para que cada um preencha da maneira que queira. Dá-se 0 início a parte prática da oficina em qualquer lugar e a qualquer instante que os participantes desejarem.

Boiadores nadam no nada: entendedores da própria vida nada entendem.

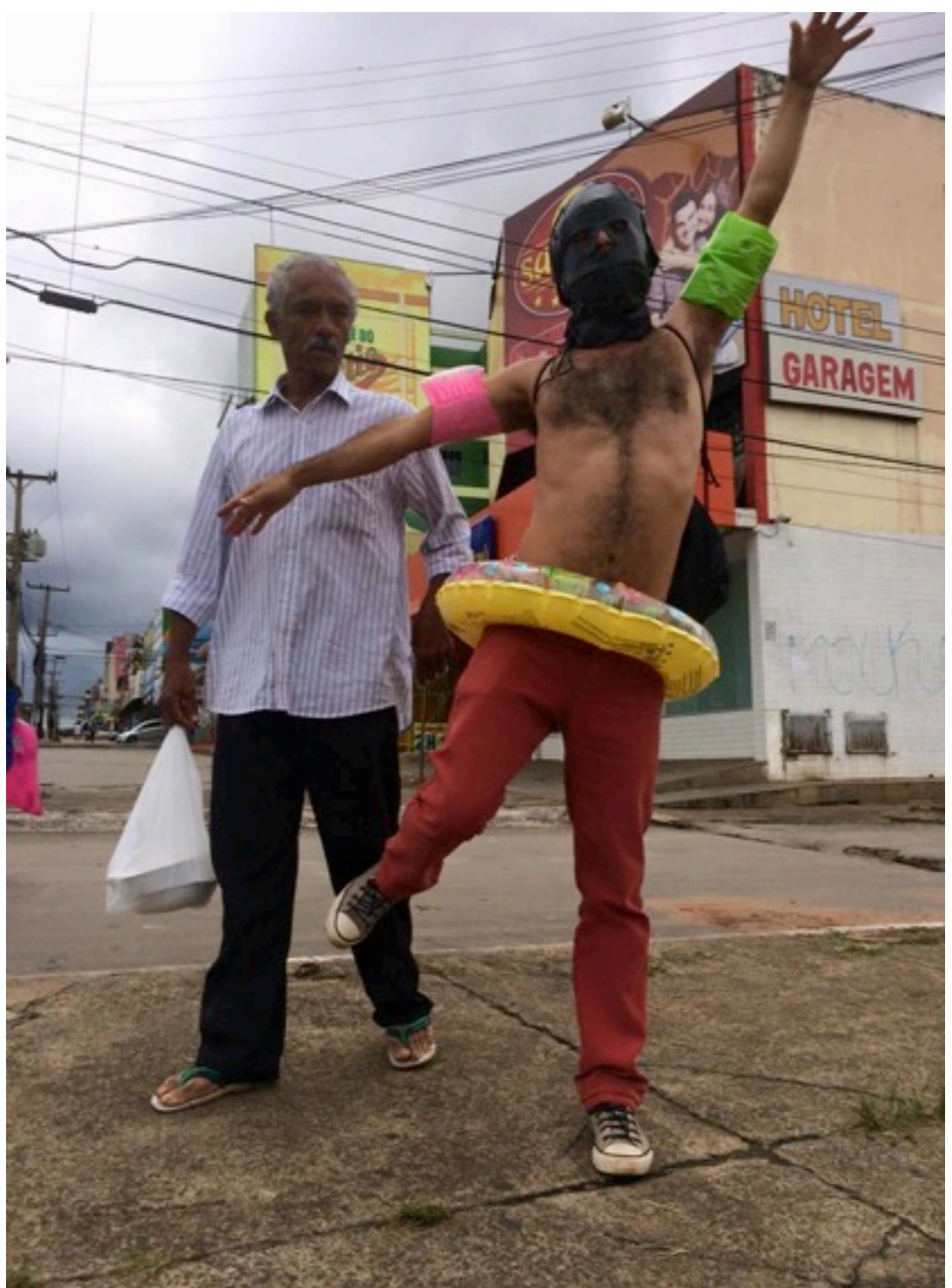

2. 
DESLIZAMENTO:

Texto sem órgãos ou corpo diluído.

Balé de autores.

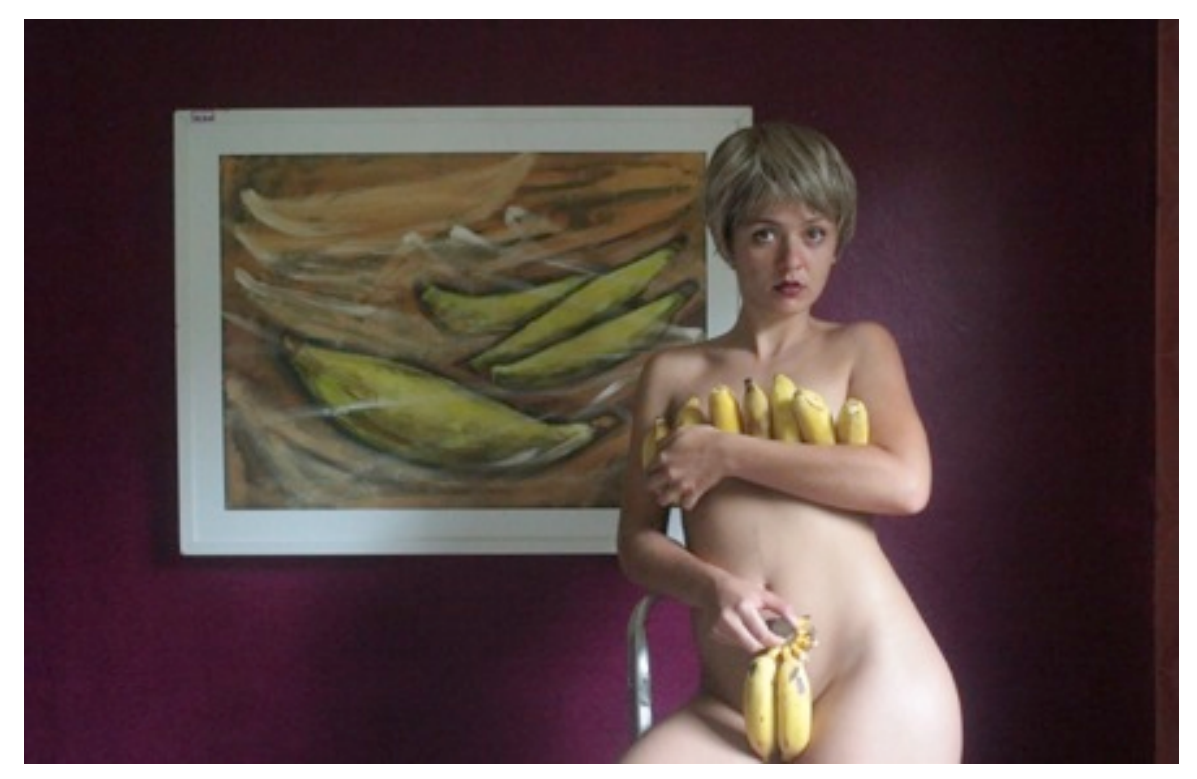

3.

Ruinscape (ing). Ruin; ruina; (ing)scape: a. Fuga, Landscape: Paisagem, 1. Horizonte de ruinas. 2. Transformação da paisagem por meio da dispersão de sua verticalidade; dispersão pela queda. 3. Construção aparente de desordem, ordem em movimento constante. Desmoronamento de expectativas.

(TAMAYO, 2014, p.119)

O deserto é o niilismo. Este possui a condição histórica de um mundo decadente: a perda, como também o perder-se. A técnica do niilismo é o abandono, a despretensão de validação, quem sabe, o deboche. Hahaha!
Abandono aqui a ideia de finalização. Não tenho um trabalho propriamente pronto. $O$ privilégio está numa obra que nunca acaba. A obra só acaba quando se abandona ou quando já está distante de sua função a priori.

Ou: daquilo que veio antes. De quê, mesmo? 


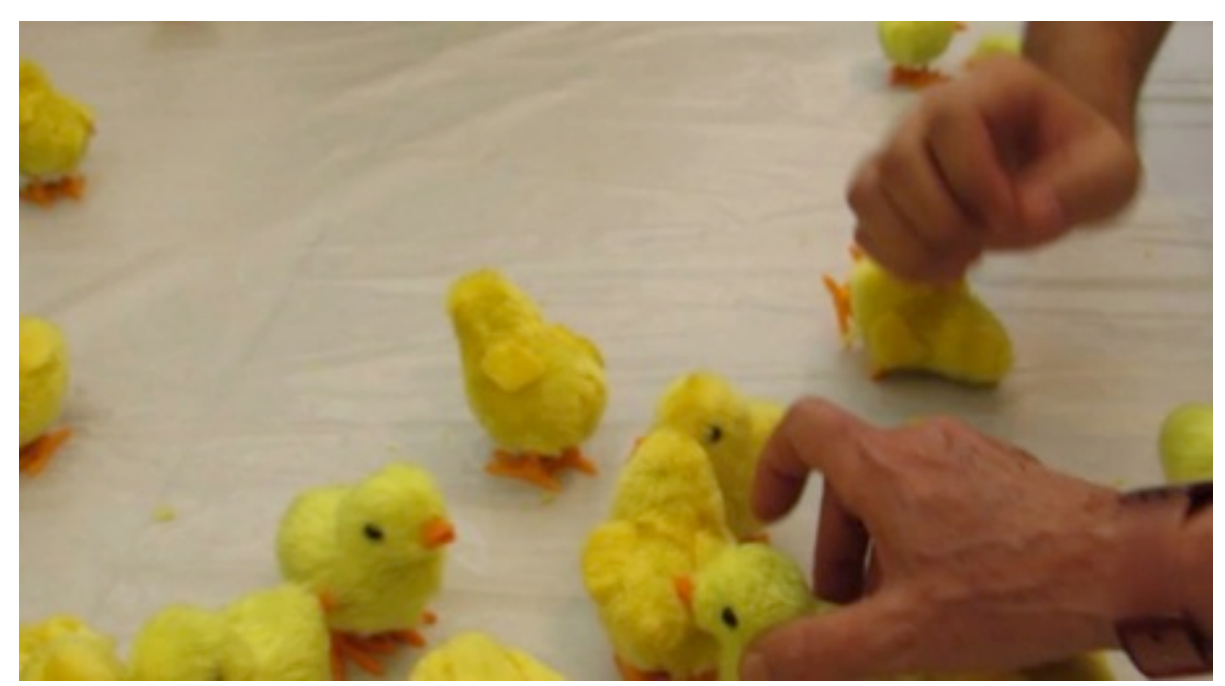

4.

Privilégio do abandono (Manuel de Barros)

Esquecimento: um novo começo.

Perder: Ser ou ficar privado de (coisa que possuía). Cessar de ter ou deixar de sentir. Não aproveitar. Deixar de viajar em um veículo por não chegar em hora própria. Perverter. Deixar de ver ou ouvir. Desperdiçar. Ser vencido em (...) Extraviar-se.

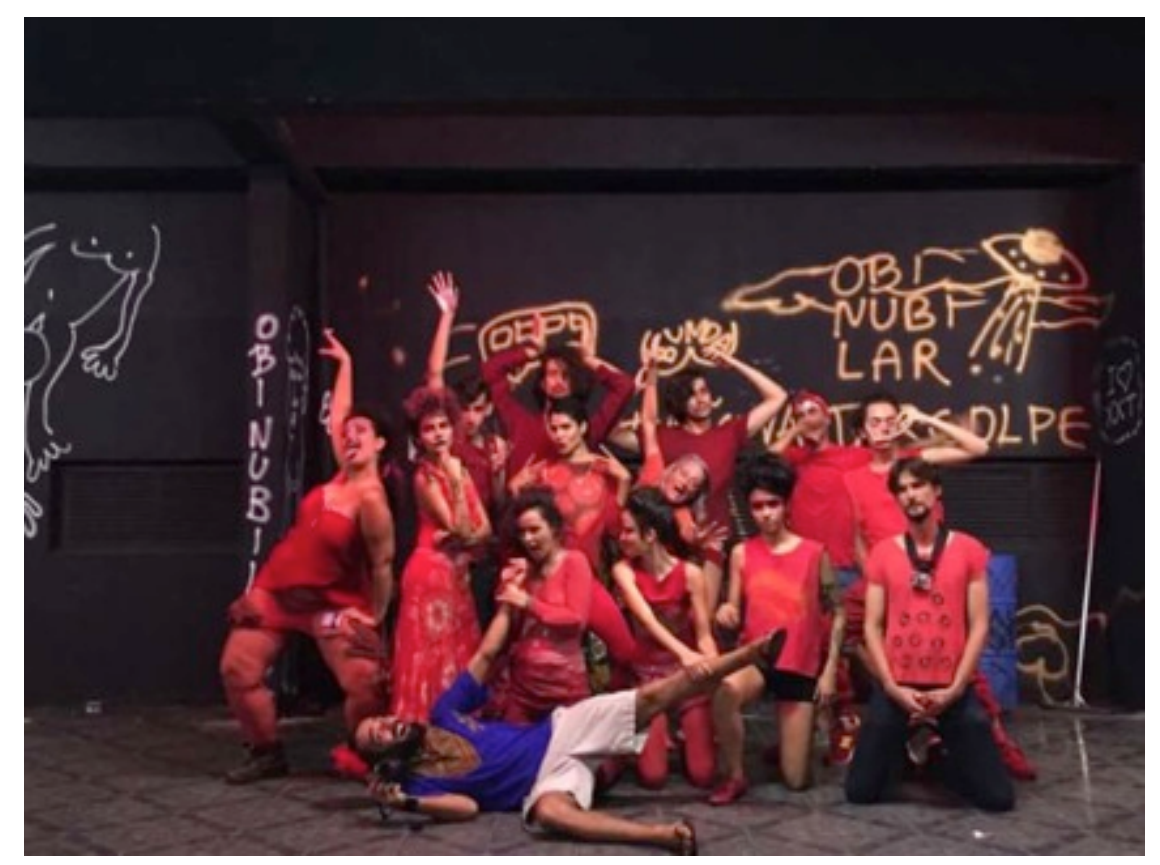

5.

Tropicália: construções espontâneas, anônimas dos grandes centros urbanos - arte das ruas, das coisas inacabadas, dos terrenos baldios etc. (OITICICA, 1968)

\section{FULERAGEM}

"fuleragem não tem definição" (MEDEIROS, inédito) -em algum momento de 2016. 


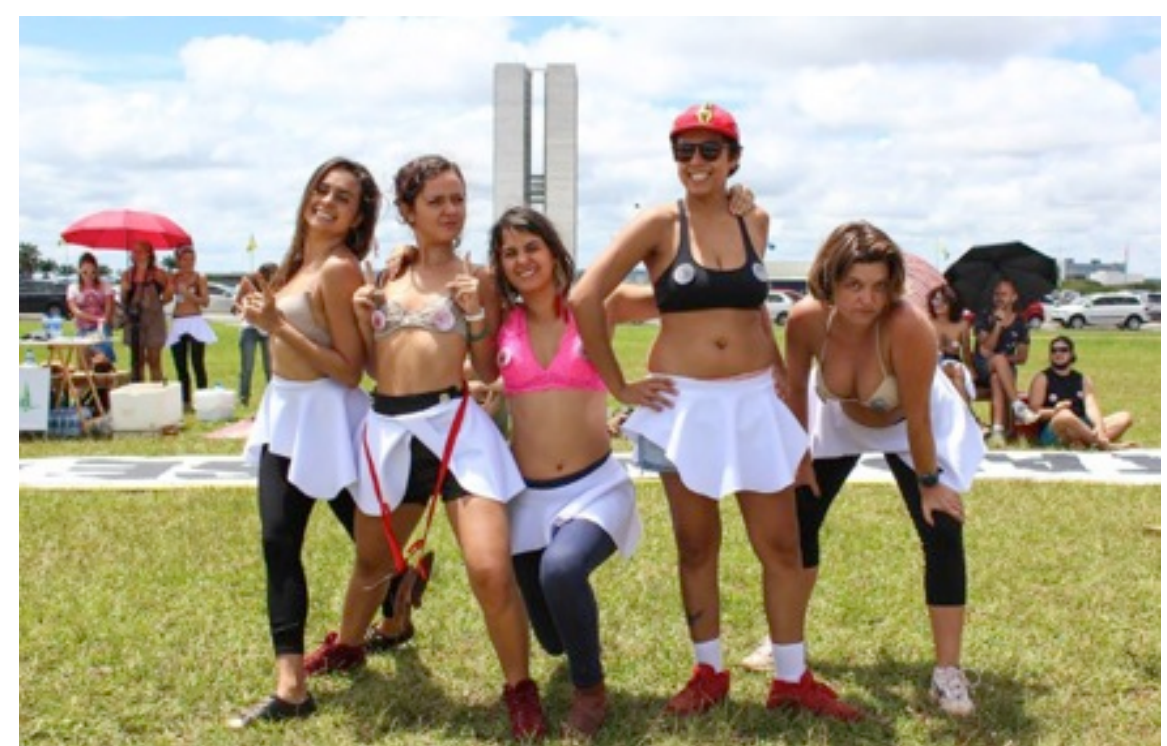

6.

Reformulação da arte em território alargado

Ocupa-se o espaço sem medi-lo

Criação: espaço ampliado

campo aberto da imagem a ser imaginativamente interpretado pelo espectador

Errantologia: mais próxima da geografia que da história, ou seja, corresponde mais com o 'estar' e o deslizamento do corpo no que existe. Vadiar. Vai além do mero conhecimento de pertencer ou não a aquele lugar.
Mitos vadios são mitos por fazer (Hélio Oiticica)

\author{
Sujeito à deriva, quando não naufragado \\ Território a ser construído \\ possibilidades
}

\begin{abstract}
"Planaridade, no original 'planitude', que em francês não designa apenas a superfície bidimensional, mas remete também a uma ideia de banalidade ou indistinção, estabelecendo aqui uma relação entre igualdade dos sujeitos e a indistinção das artes".
\end{abstract}

(PECORARO, 2007, p. 22)

Tanto faz se é performance ou não: valor dado à indeterminação entre uma situação comum e uma situação de desvio: performance; vista como arte, ou que alimenta-se da arte, ou é vista como uma patologia quando não percebe-se seu disfarce, ou não é vista como nada, dada como normal, insignificante. Permeia entre a banalidade fuleira em instituições de arte e o estranhamento pertinente em ambientes normativos não artísticos - ou: composição urbana.

A performance, por estabelecer um status de arte, ainda mantém-se distante da vida ou do que não é arte, ou seja, quando é dado o nome de "performance" ou "arte" a uma situação de desvio, há uma tendência da ação justificar-se e de não questionar-se, não duvidar-se; por isso,

tanto faz. 


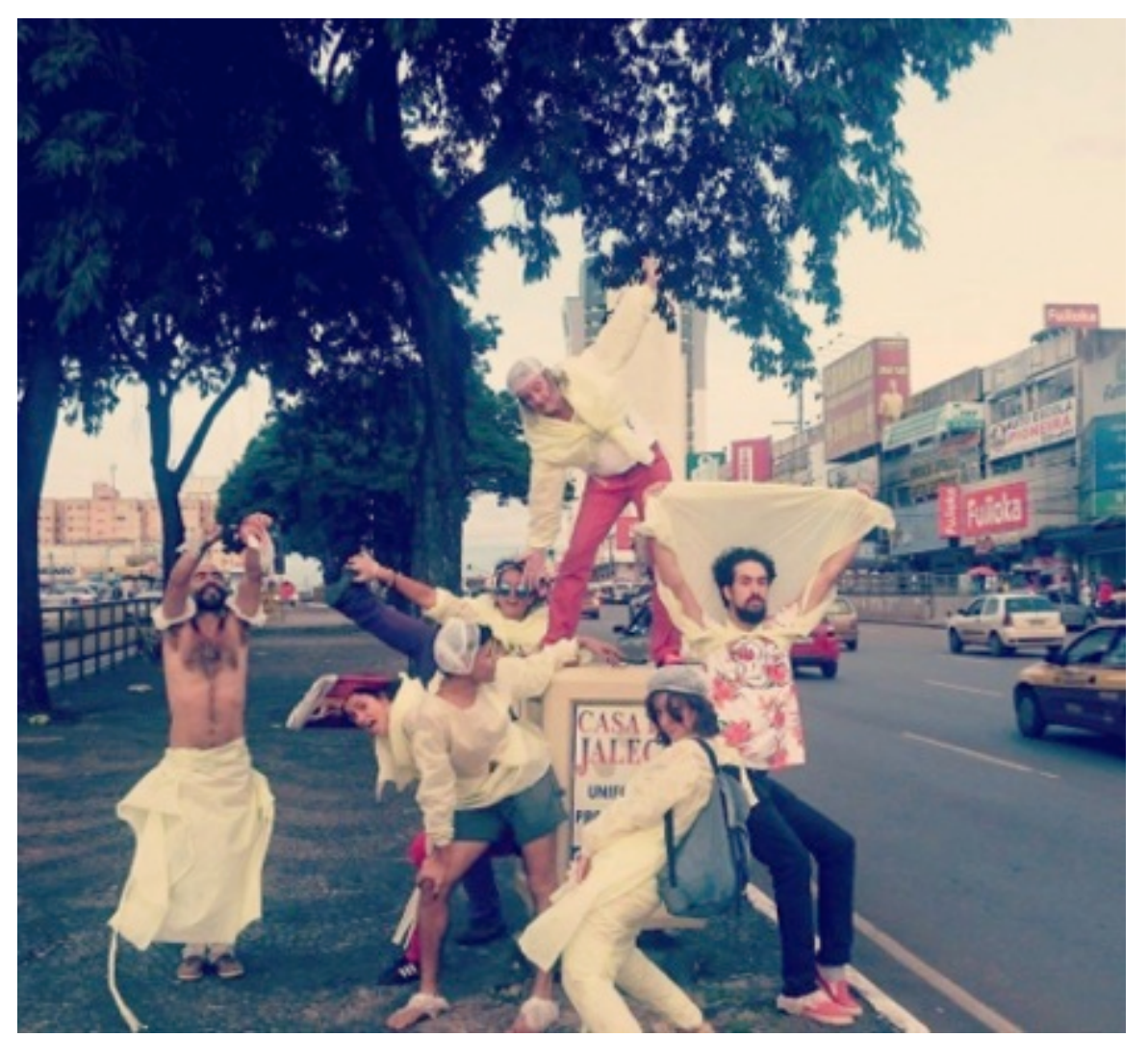

7.

Flutuar: Como nadar, há grande importância do emprego metafórico deste verbo

Acaso: Conjunto de casas independentes entre si que, por leis ignoradas, que determinam um acontecimento. Acontecimento fortuito. Casualidade, possível, porém improvável. Existência absurda e gratuita vivida sem motivos ou explicações.

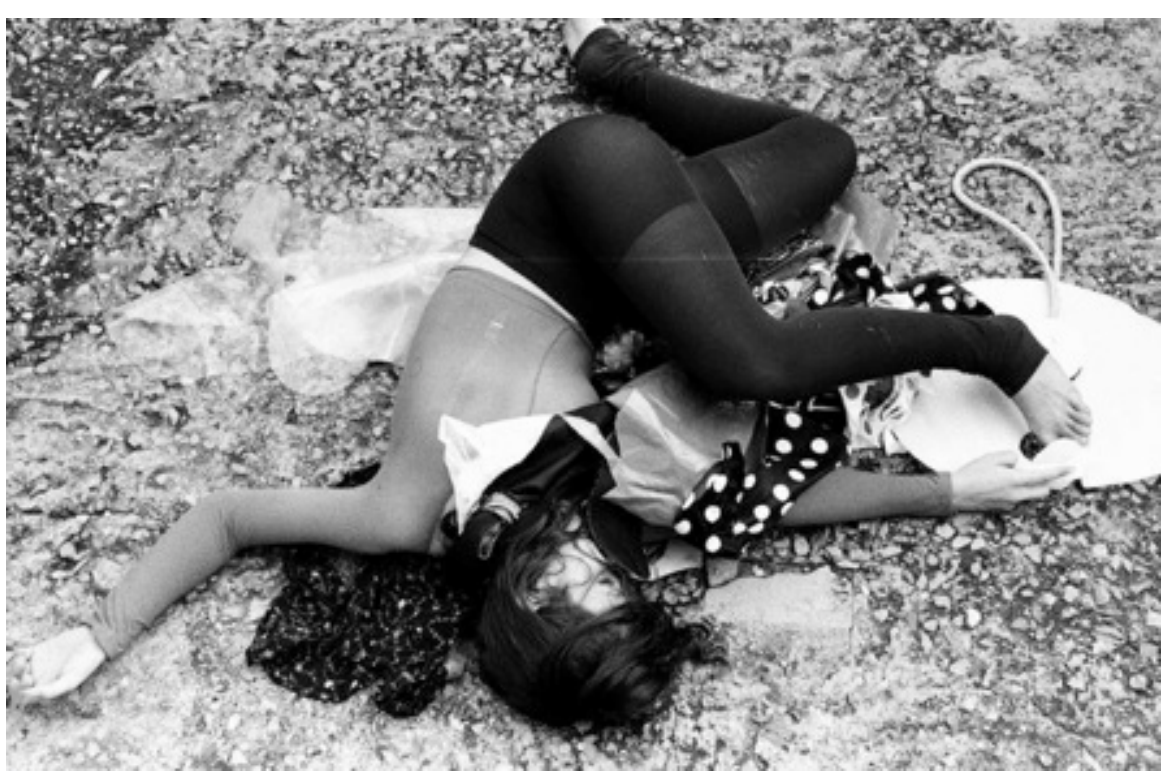

8.

"Criação como ficção (phatos+logos). A arte como 'coreografia' do real, 'entidade com o poder de coordenar elementos heterogêneos, díspares da natureza..." Desejo de reposicionar as coisas"

(TAMAYO, 2014, p. 210)

"O avesso é seu verdadeiro direito,

seu corpo sem órgãos que sente sem o automatismo"

(fragmento oral da peça: Pra dar um fim no juízo de Deus. Dirigida por José Celso Martinez. Brasília, 2016)

"O estado estético é a visualização por meio da qual constantemente olhamos, de modo que aqui tudo pode ser atravessado pelo olhar" (HEIDEGGER, 1889, p.127) 


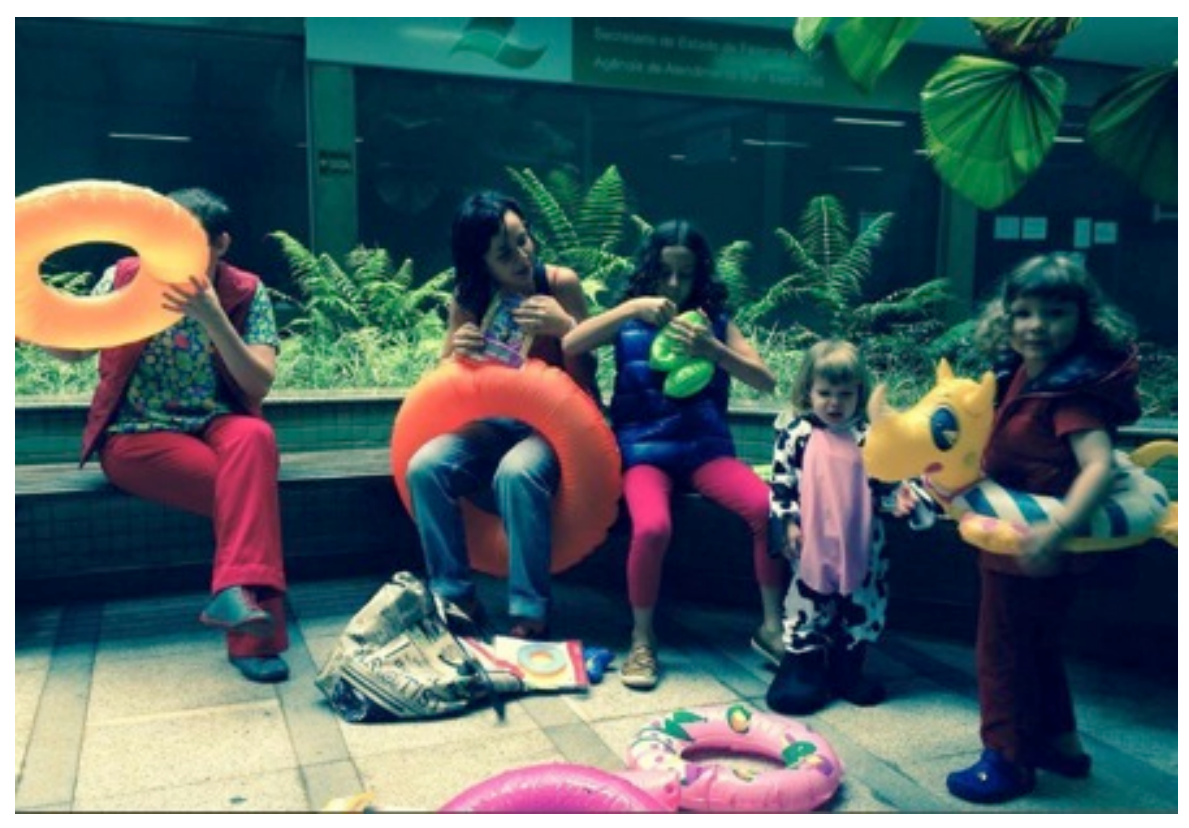

9.

Deslizamento

Estado gasoso: zona de indeterminação e potência desejada para a ambivalência e dispersão, (...)

do que não pode ser delimitado, do que está em suspensão no ar.

"A Composição Urbana não é nada, ela pode ser tudo aquilo que, em espaços de circulação pública, renova o sentido cotidiano (...)" (ALBUQUERQUE \& MEDEIROS, 2013, p.29)

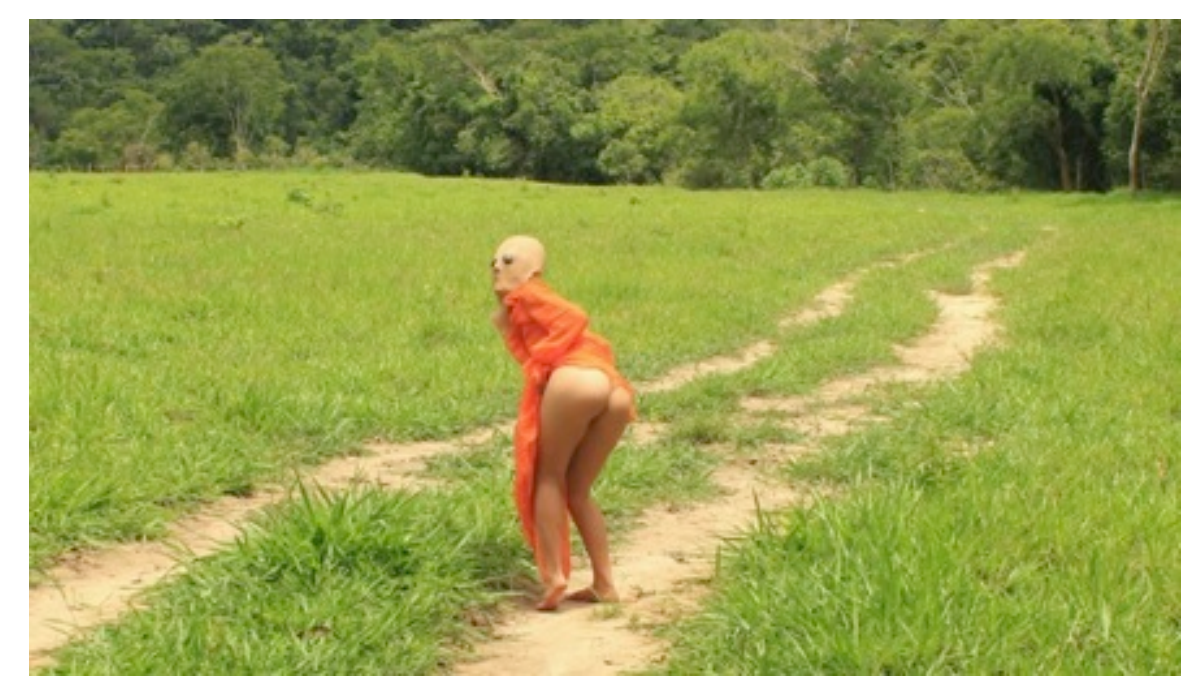

10.

Risco: Qualquer traço em cor, ou sulco pouco profundo na superfície de um objeto. Delineamento ou esboço. Desenho para ser bordado. Traço sem valor. Perigo mais possível do que provável.

"Todavia, os blocos precisam de bolsões de ar e de vazio, pois mesmo o vazio é uma sensação, toda sensação se compõe com o vazio, compondo-se consigo, tudo se mantém sobre a terra e no ar, e conserva vazio,

se conserva no vazio conservando-se a si mesmo" (DELEUZE, 1992, p. 195-196) 


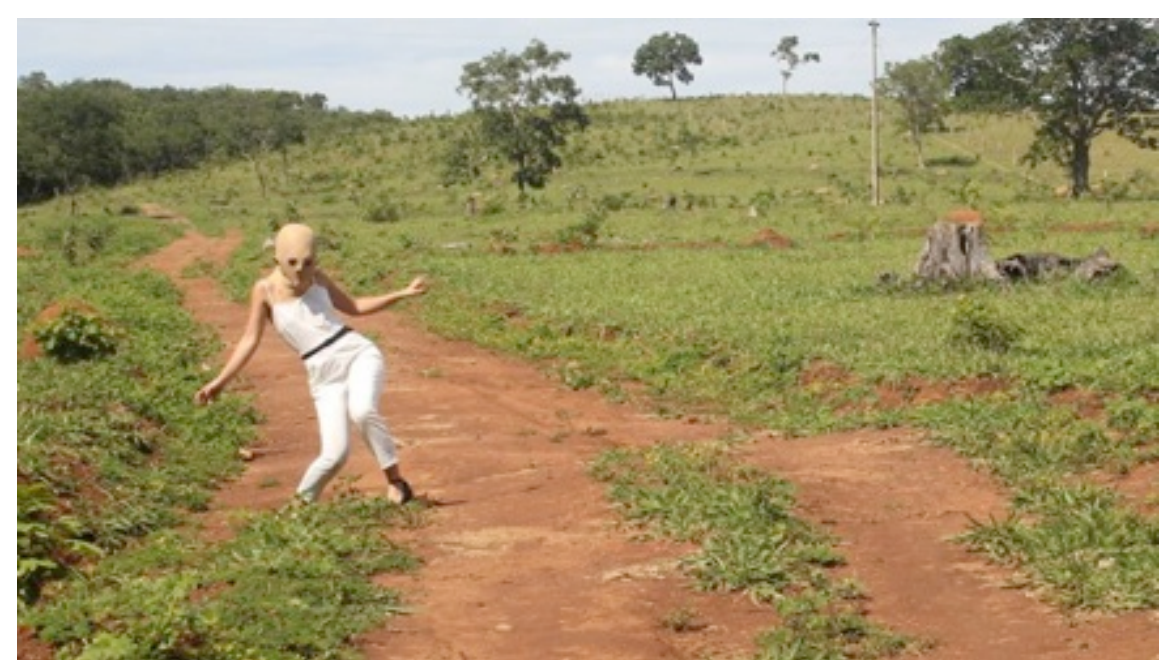

11.

Visibilidade: o lugar que ocupam.

Hermético: inteiramente fechado, de sorte que 0 ar não possa entrar.

De compreensão dificílima.

Lógica nômade: bandos, margens, percursos, movimento. Não ver um mapa de cima, mas de dentro.

"Quando Jeff Koons era criança, seus pais Ihe deram uma boia inflável que the permitia nadar sozinho. Ele adorou esse 'efeito libertador' e admirava infláveis como artefatos que salvam vidas e que dão uma 'noção de equilibrio'. Par Koons, os infláveis também são antropormóficos. 'Nós somos infláveis', ele diz com uma candura evangélica. 'Nós inspiramos e isso é símbolo de otimismo. Nós expiramos, isso é símbolo de morte'."

(THORTON, 2015, p.19)

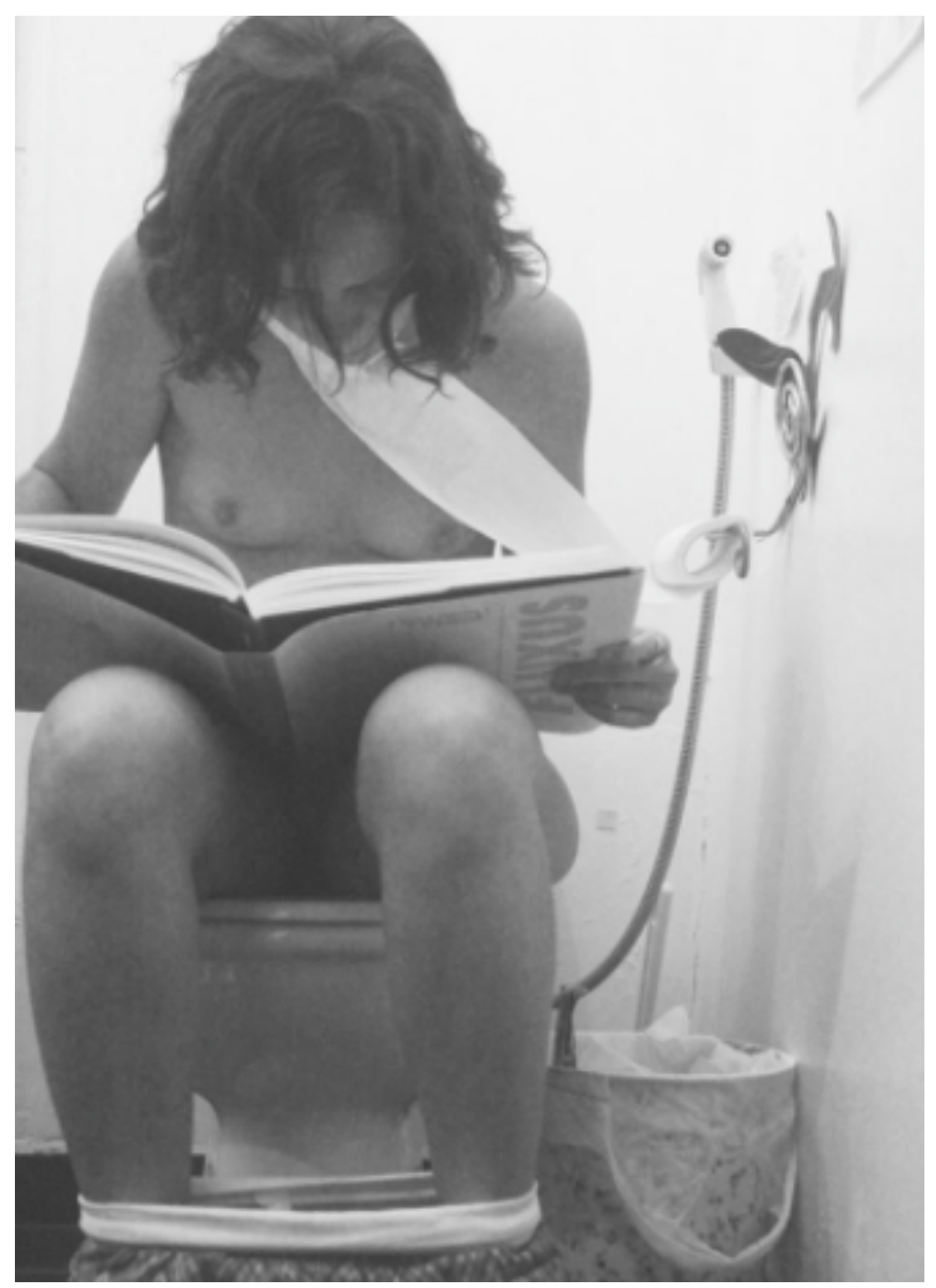

12. 
FLUXUS: do Latim, estado não determinado, flutuante, transitório. 0 termo 'Fluxus' passou a designar e caracterizar uma série de performances organizadas por George Maciunas na Europa durante a década de 60. (esta definição está correta?)

Boia: peça de material flutuante. Material que se apoiam aqueles que aprendem a nadar. Qualquer objeto flutuante sobre a água que auxilie a natação. Peça no reservatório de água que impede que ele se encha. Grão de café chocho que sobrenada nos lavadouros. Obra de mercadoria que não foi vendida (abandonada).

\section{Boiada: manada de bois.}

Boiadouro: Trecho de rio onde emergem e boiam tartarugas.

Boiar: sobrenadar, flutuar. Os mortos boiam no rio. Balançar, ocilar.

Estar irresoluto, hesitar. Sobrar, restar. Não entender.

John Cage lança a percepção do momento, ou melhor, do tempo-espaço. Não se sabe onde começa e onde termina. Ele percebe que a música fala de sentimentos internos e que o ruído, o som do tráfego, dos passos; não significam nada, não se pensa sobre eles. É este vazio que interessa a ele, onde não há a sensação que alguém esteja falando (não-narrativo). Os barulhos da rua e das coisas consideram-se como o silêncio. O momento de se escovar os dentes, de comer, se vestir, ligar e desligar a luz podem ser consideras ações vazias por serem ações comuns em que se repetem todos os dias. É por essas e tantas repetições que se encara a ação como automática, passando se despercebida.

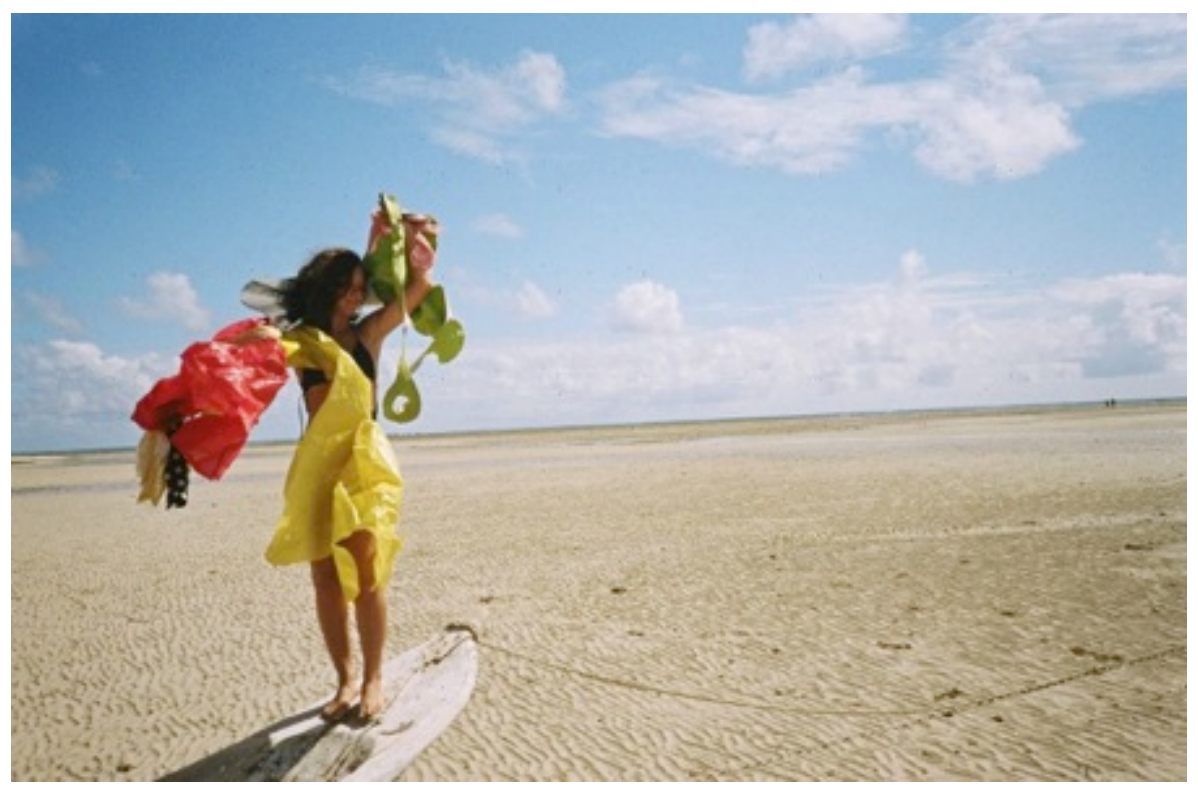

Flutuação: Movimento oscilatório, ondulação. Mudança de ideias de opiniões, indecisão, vacilação. Instabilidade da cotação de preços e valores em um determinado mercado ou praça. Variação alterada. Na estatística é a diferença entre valor instantâneo e o valor mais provável desta variável; dobro de variância de um conjunto de valores. Variação morfológica não hereditária, modificação somática, somação. Afastamento, em relação ao valor médio ou ao valor mais provável, do valor de uma grandeza do sistema.

\section{Narrativa como dança -percurso errante- viagem}




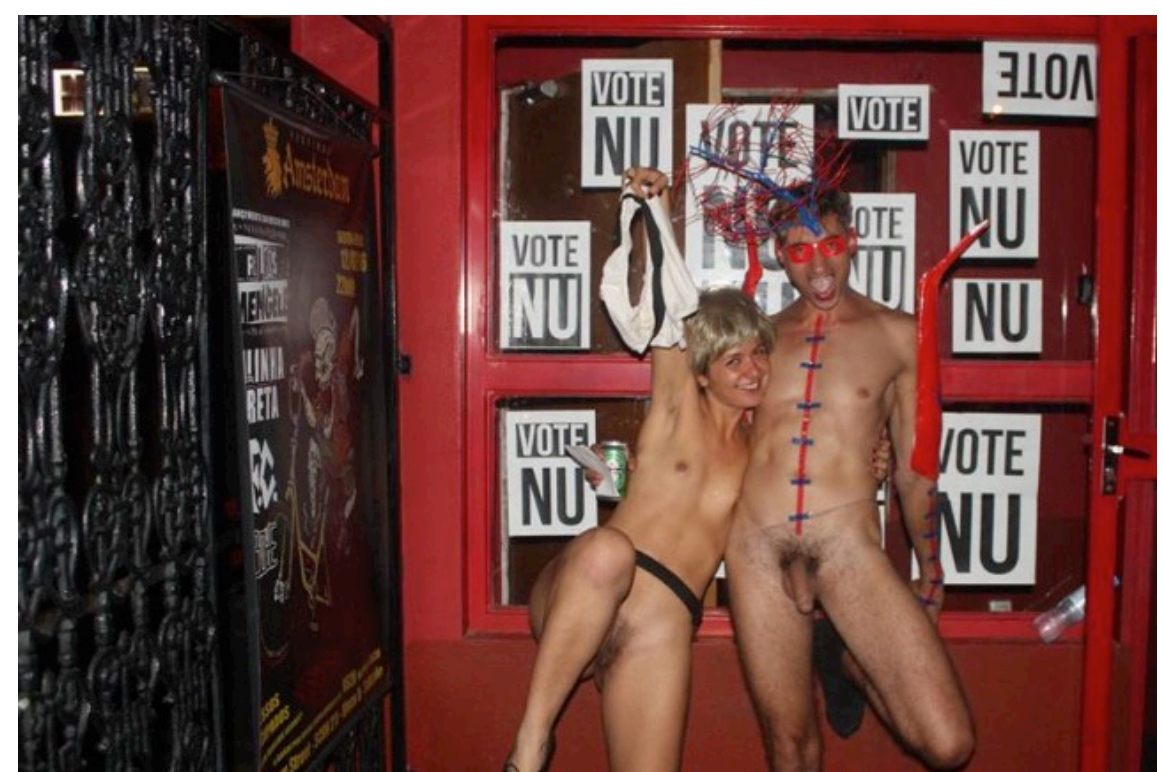

14.

Deriva: Modo de comportamento experimental ligado às condições de sociedade urbana: técnica de passagem rápida por ambiências variadas (...) Confusão passional pela rápida mudança de ambiente.

(Definições sobre a Internacional Situacionista. Revista $n^{0} 1$ junho de 1958)

Comunidade coreográfica: idealizada por Platão, é um grupo que canta e dança sua própria unidade com dois movimentos antagônico - simulacro da cena/identificações do público + movimento autêntico do próprio corpo.
"Os três verbos (nadar/flutuar/navegar) não parecem estanques podendo ser substituídos, bem como membros da mesma classe entre sí (boiar/singrar) no sentido físico e metafórico. Um exemplo é o verbo navegar (56) podendo ser substituído por nadar, flutuar ou boiar, apontando a DERIVA SEMÂNTICA no sentido da diluição do sentido específico

de cada um destes itens lexicais." (BATORÉO, 2006, p 186)

Também. Pode?

Invocar o outro ao pensamento e ação. Neste caso, invocar também ao movimento antagônico de descansar e não aprofundar em pensamentos, apenas superfície. Levar as coisas para passear, viajar, navegar, flutuar, diluir em universos vazios

(...) de sentido.

Se perder por não seguir os caminhos planejados e botar-se à deriva dos caminhos guiados pelo acaso e pelo sentir (Paola Jacques)

Experiência não planejada,

o corpo que vive o que não espera, pedaços de anotações embaralhados ao acaso.

Na água a forma e o texto se desintegram;

como uma História abolida com um sentido refrescante que fura a pressão existencial cotidiana. 


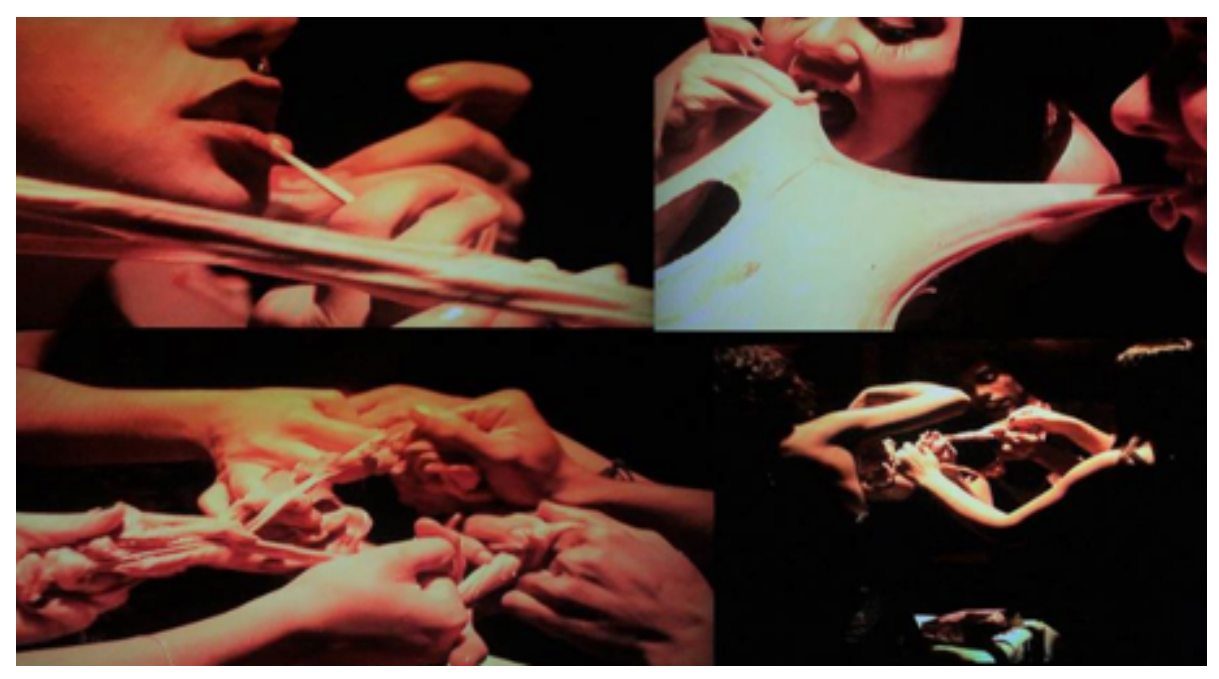

15.

Ilhas de sentido ou ideias sem sentido: nem fixo nem inapreensivel; produtoras de arquipélagos aleatórios destinados à decomposição.

Avesso do corpo: corpos sem órgãos, boias sem órgãos, espaço sem órgãos. 0 avesso do movimento sem saber ou nádegas a declarar. Presença não sossegada do corpo, desparecimento por saco cheio,

movimento ambíguo ondulatório.

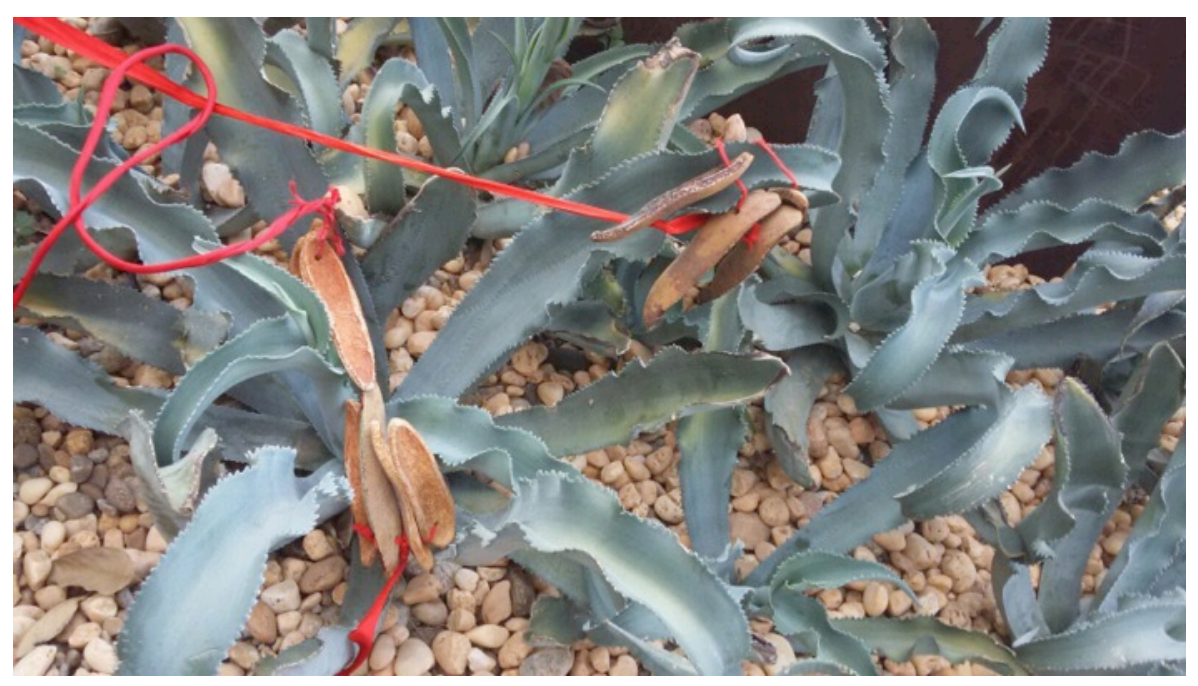

16.

Hermético: Inteiramente tapado de maneira a impedir a passagem de ar, selado ou lacrado. De difícil compreensão ou tende a ser obscuro ou pouco claro, enigmático: texto hermético. Que pode se referir a alquimia ou ao Hermes.

"A escolha destes Ready Mades jamais foi ditada por um deleite estético - a escolha foi feita com base em uma reação de indiferença visual e ao mesmo tempo uma total ausência de bom ou mal gosto. De fato uma completa anestesia."

(DUCHAMP. Sobre Ready Mades. 1961) 


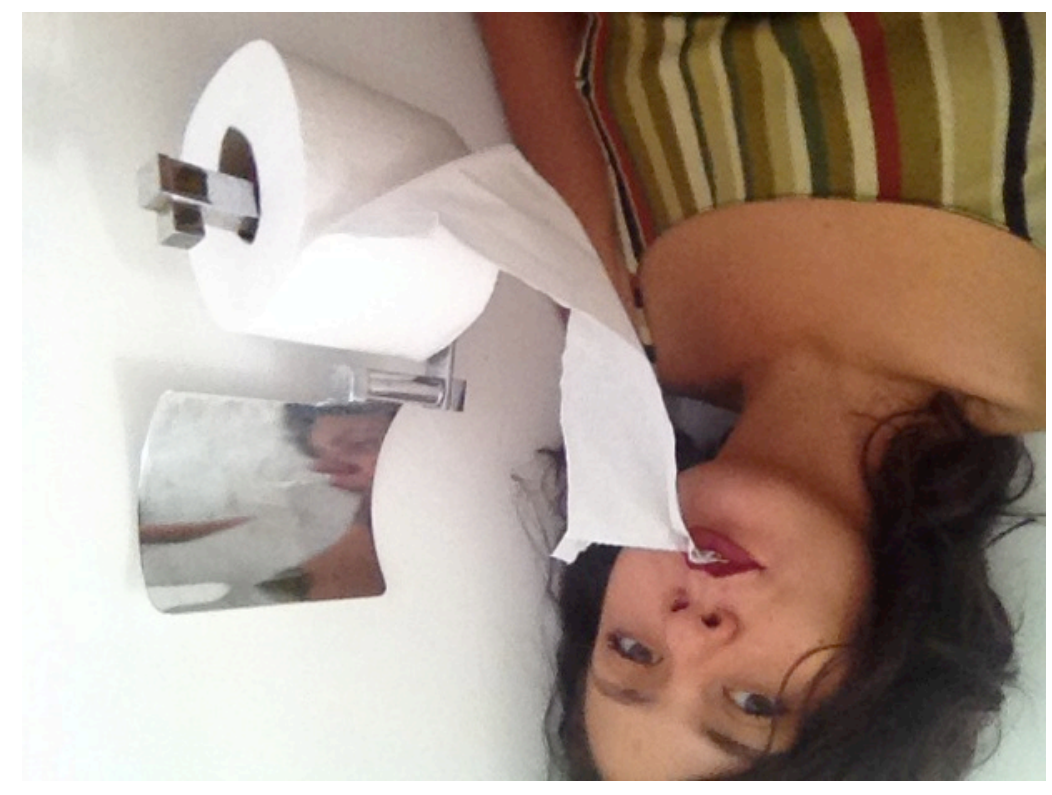

17.

Entropia: encontro o indivíduo com a transitoriedade.

Medida de desorganização. 0 aumento da entropia é o aumento de desordem. Caos, balé entre as coisas o qual nada é sincronizado.

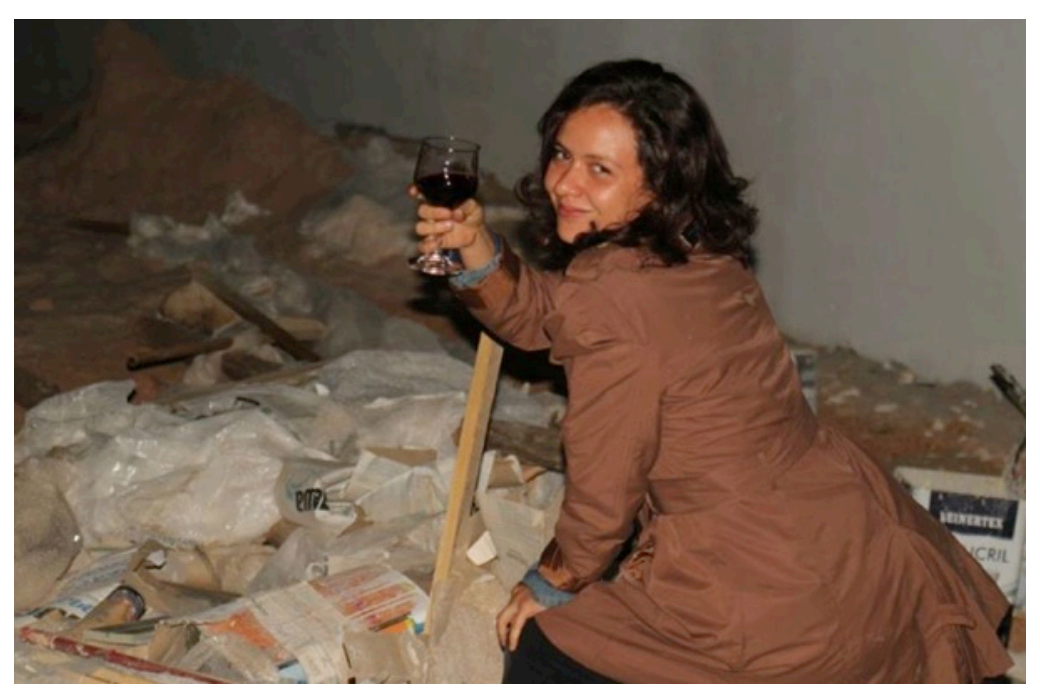

18.

\section{"É triste como o ar é}

A única coisa que compartilhamos

Não importa o quanto nos aproximamos

Sempre existe ar entre nós

Também é agradável que compartilhamos o ar

Não importa o quão distante estivermos

O ar nos conecta"

(YOKO ONO, Air Talk, 1967)

-apud Nina Orthof- 


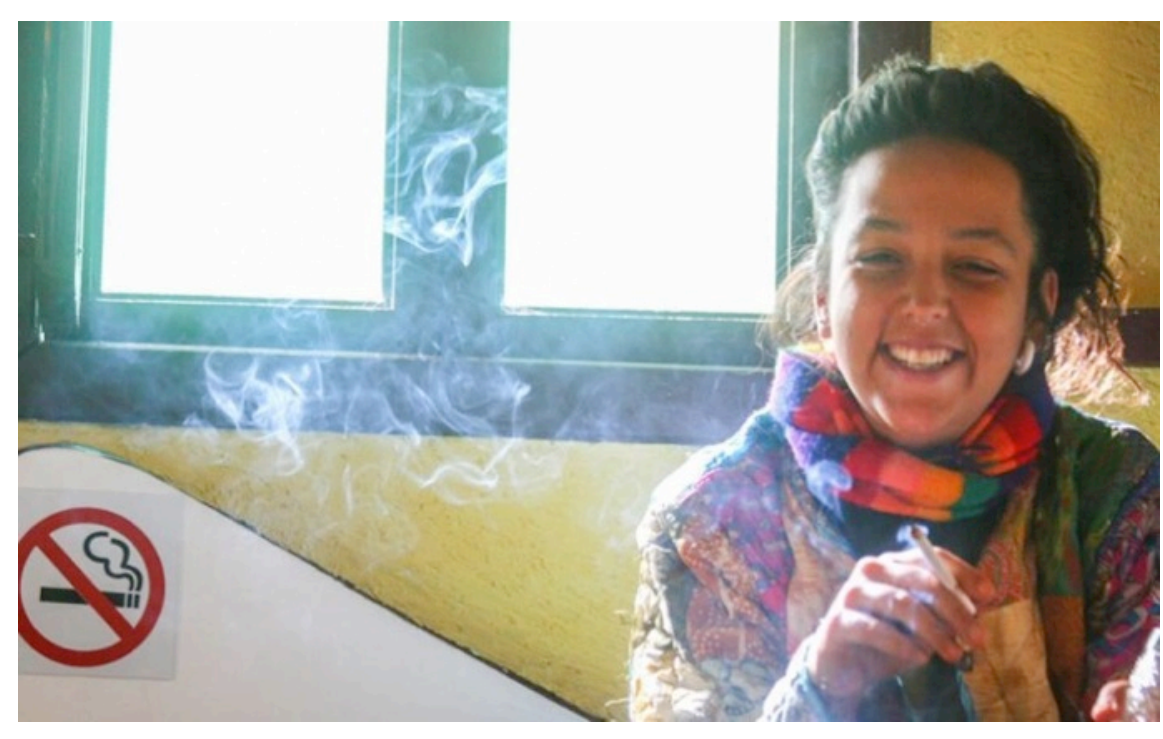

19.

Do extinto de brincadeira se faz um fenômeno estético.

"A transitividade provoca desordem da formalidade do diálogo- ela nega a existência de um 'lugar de arte' e quer uma discursividade sempre inacabada e um desejo de contaminação."

$$
\text { (BOURRIAUD, 2009, p.36) }
$$

\section{Diluir decisões é parte de boiar.}

Pela flexibilidade da interpretação.

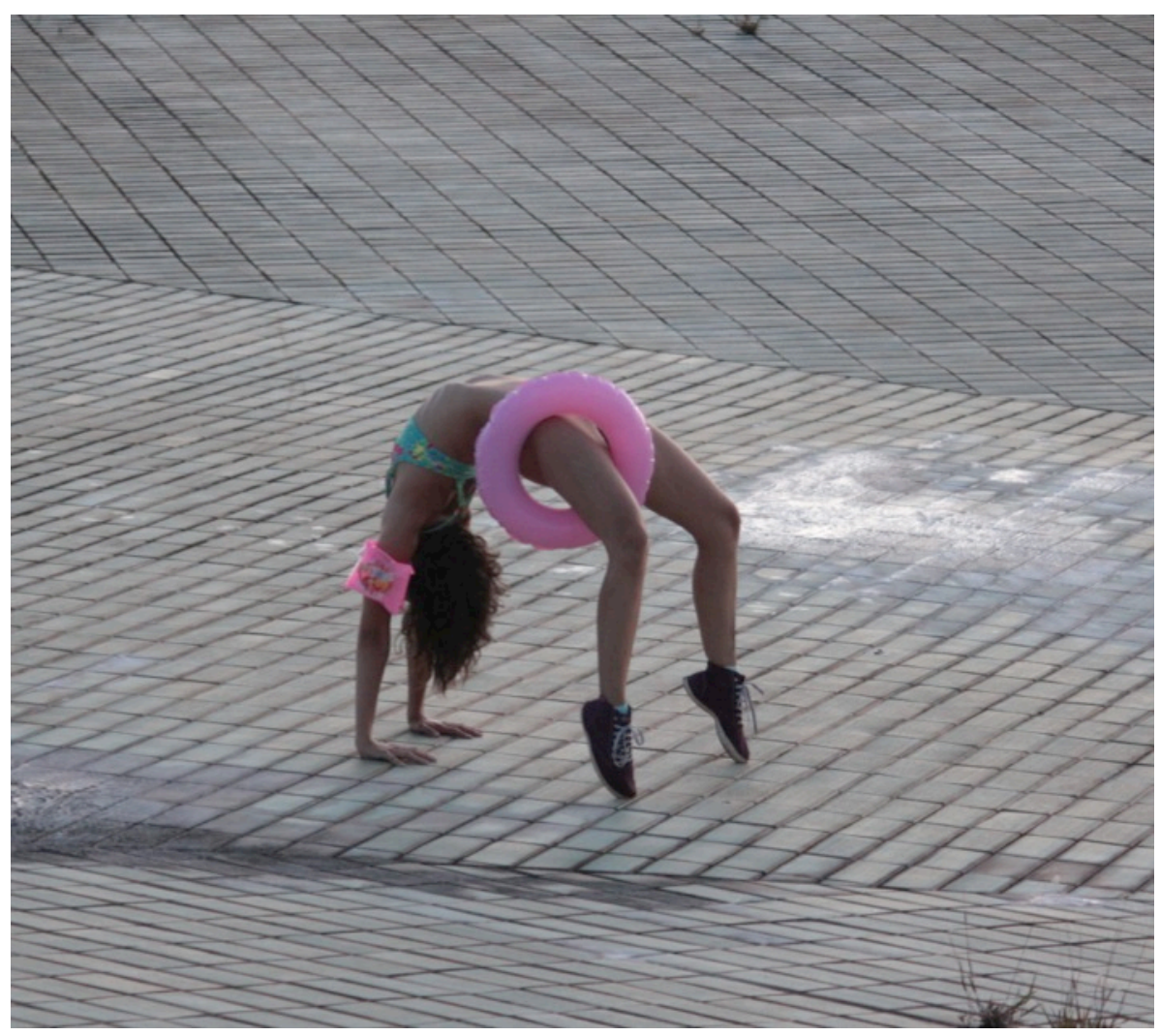

20

Delírio Ambulatório: como um explorar de um grande labirinto. Reconstruir o mundo como um caótico quebra-cabeça a ser esmiuçado e reinventado.

Labirinto: espaço estriado de Deleuze e narrativas não lineares que Hélio Oiticica chamava de não-narração. 
O que o conceito diz, desdiz; se afirma e renega; traz a dúvida se é estagnado ou sua ironia traz o dúbio e múltiplas facetas para a arte. O que busco é o trânsito antagônico em embate ou simbiose, diluição dos sentidos precisos, dúvida entre arte ou vida. Este é RISCO da mistura, de contaminação: aplauso e descaso sobre um mesmo delírio.

\section{Unidade dupla - Paridade harmoniosa}

"Quando se pede em um grupo que alguém narre alguma coisa, o embaraço se generaliza. É como se estivéssemos privados de uma faculdade que nos parecia segura e inalienável: a faculdade de intercambiar experiências. "

(BENJAMIN, 1994) in (JACQUES, 2012, p.16)

"Nos reorganizamos em nós mesmos por sermos um conglomerado de coisas que não necessariamente dão cero. Somos temporais e frágeis, mas nós temos uma certa força por sermos remendados e reparados. Esse entremeio da existência..."

(Kiki SMITH) in (ORTHOF, 2016, p. 136)

Não se pretende chegar à uma negação dialética, mas em uma afirmação dúbia, diluída, duvidosa e frágil. A aceitação do múltiplo como devir da existência. Corroer as certezas de cada dicotomia. Pontos de suspensão.

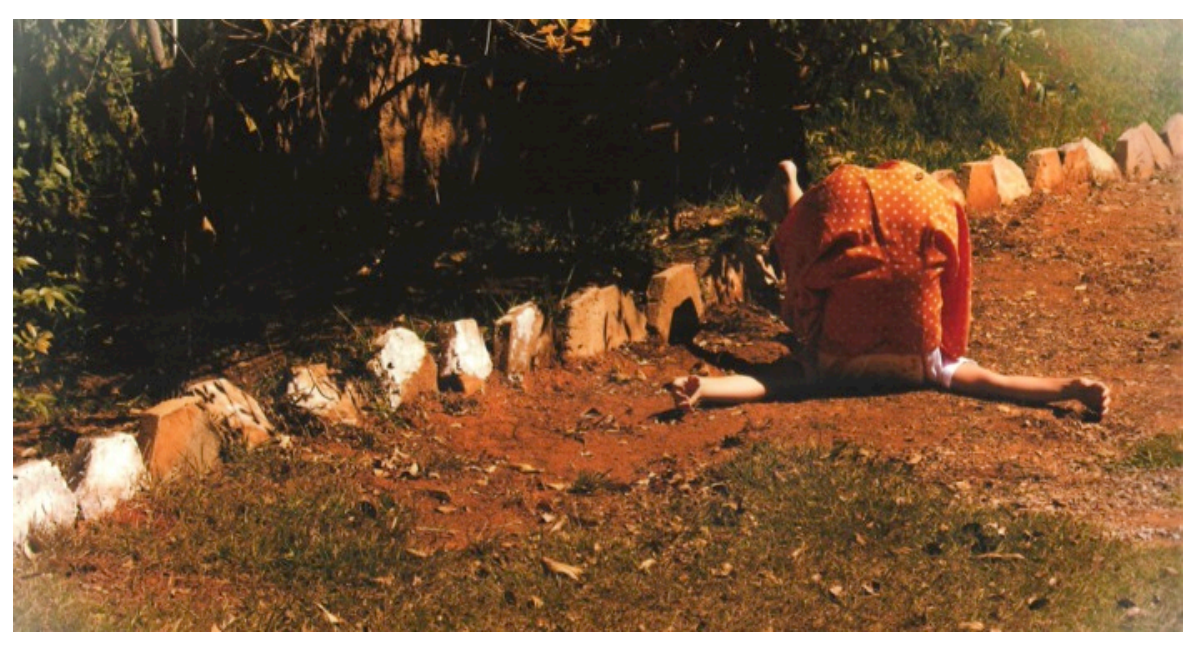

21.

"Na arte não há garantia, nem padrão (...)

Não se auto define quando não se sabe ao certo o que é."

(DANTO, 2006, p.125)

O niilismo como fenômeno histórico ligado à crise na modernidade. Surgiu no sentido estrito, no Séc. XIX ao se usar filosoficamente; mas na Revolução Francesa (Séc XVIII) foi utilizado etimologicamente meio aos debates e as controversas do idealismo: definição de quem não era nem a favor nem contra a revolução. 


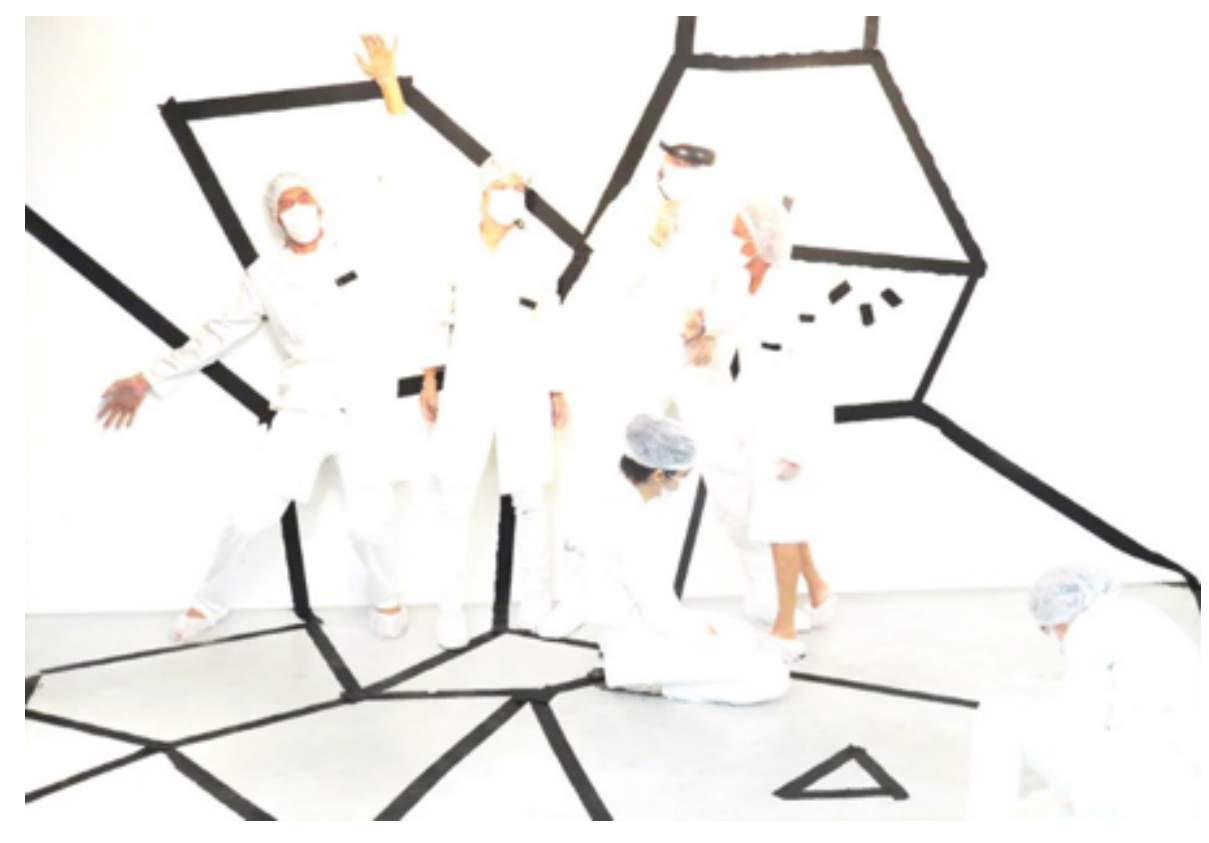

22.

\section{Lição de perplexidade:}

coincidência dos opostos, padecimento das contradições, plano de fuga.

"(...) embora o mundo da arte se mostre favorável ao 'diálogo', ele evita perguntas constrangedoras e se refugia na perplexidade

sempre que the parece oportuno."

(THORTON, 2015, p.10)

criação em branco para que se suje facilmente.

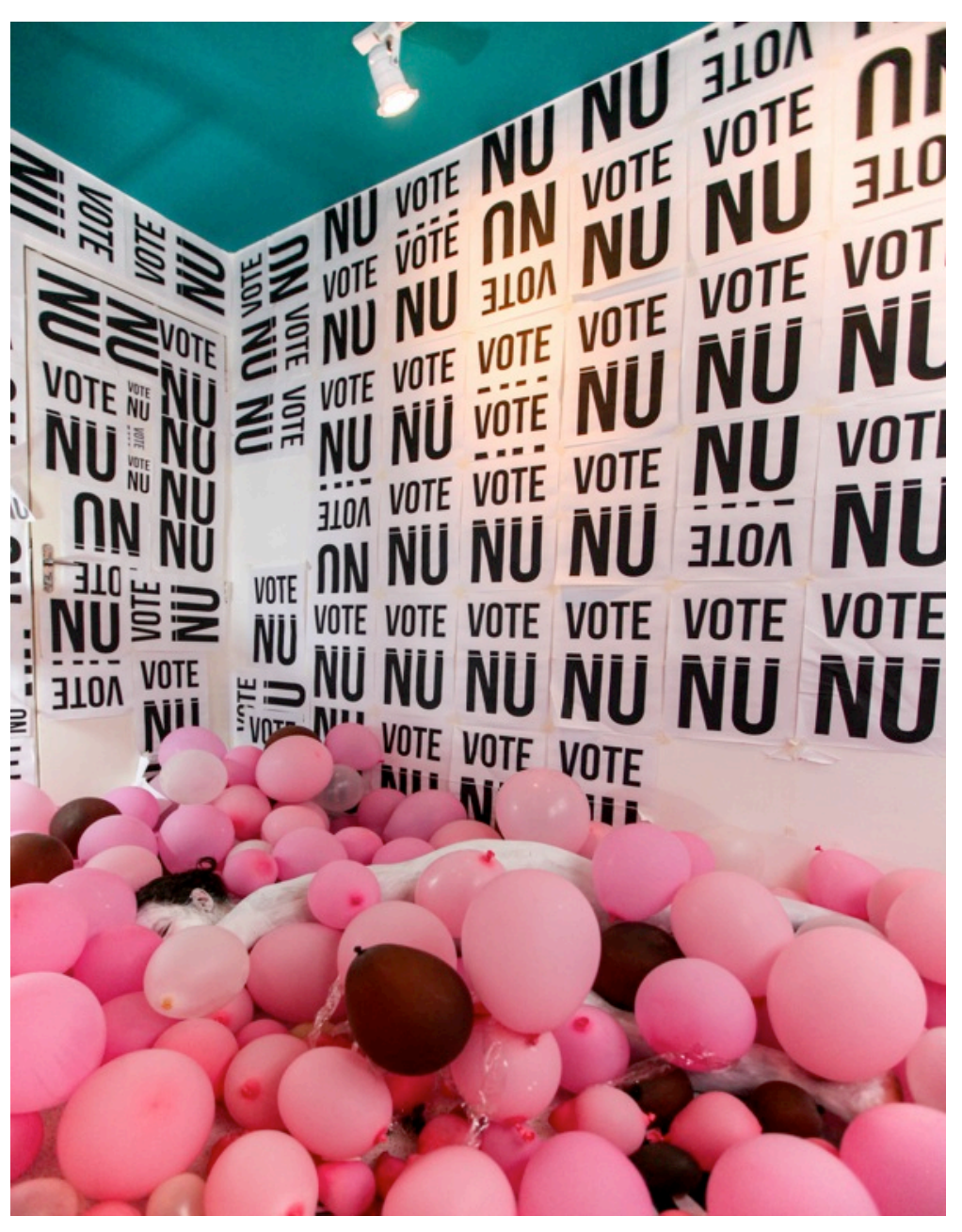

23.

“(...) transferência do artista para o público como uma osmose estética (...)” (DUCHAMP, O Ato Criador) 


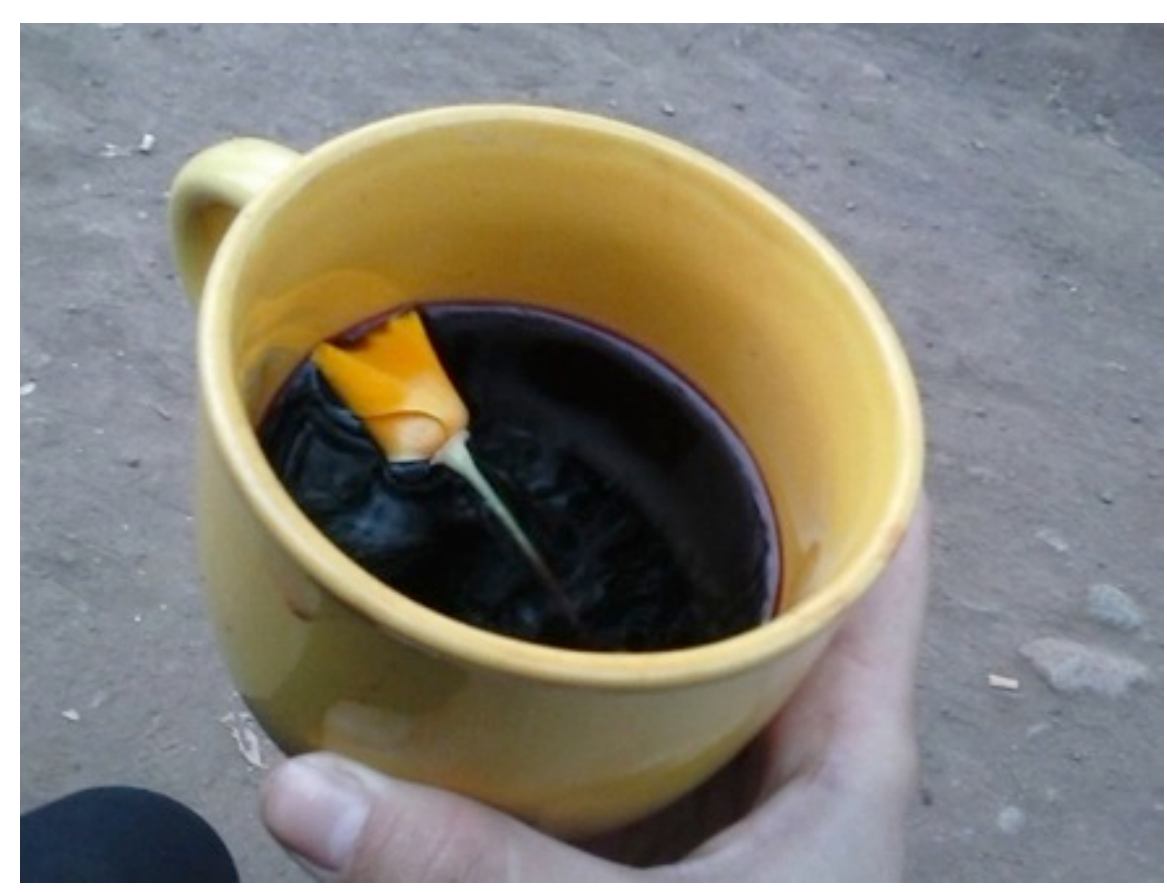

24.

"A contraposição de uma estrutura determinada a elementos imprevisíveis e ingovernáveis pode criar resultados mágicos (COTTON, 2010, p. 47)

A forma é um princípio de aglutinação (BOURRIAUD)
Viajar é estado do entremeio. (ONFRAY)

o niilismo é positivo por se harmonizar no caos. (PECORARO)

Allan Kaprow: Arte-arte, anti-arte, a-arte, a-artista, não-artista.

-transformar a arte em senha para a ironia.

\section{não separar os termos}




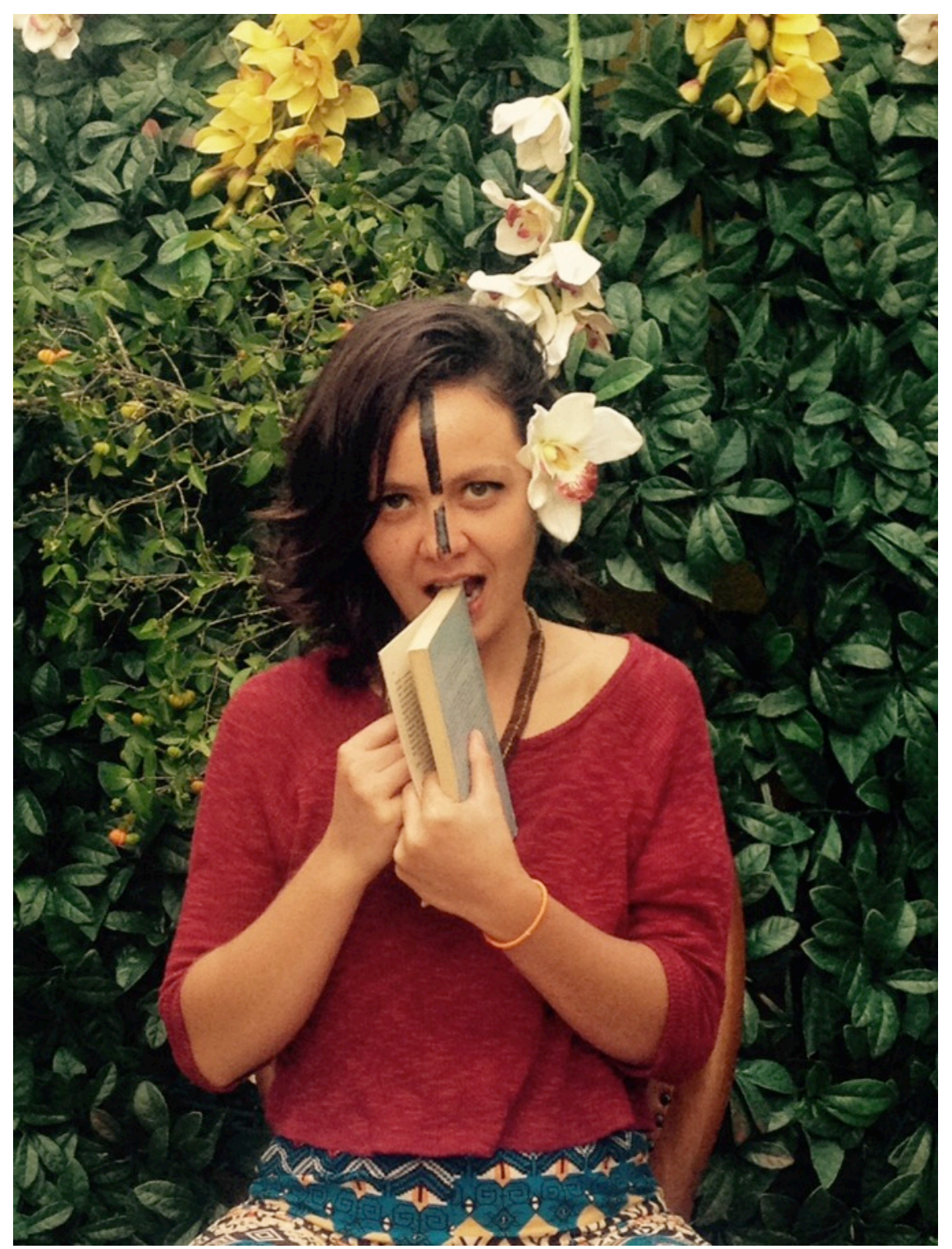

25.

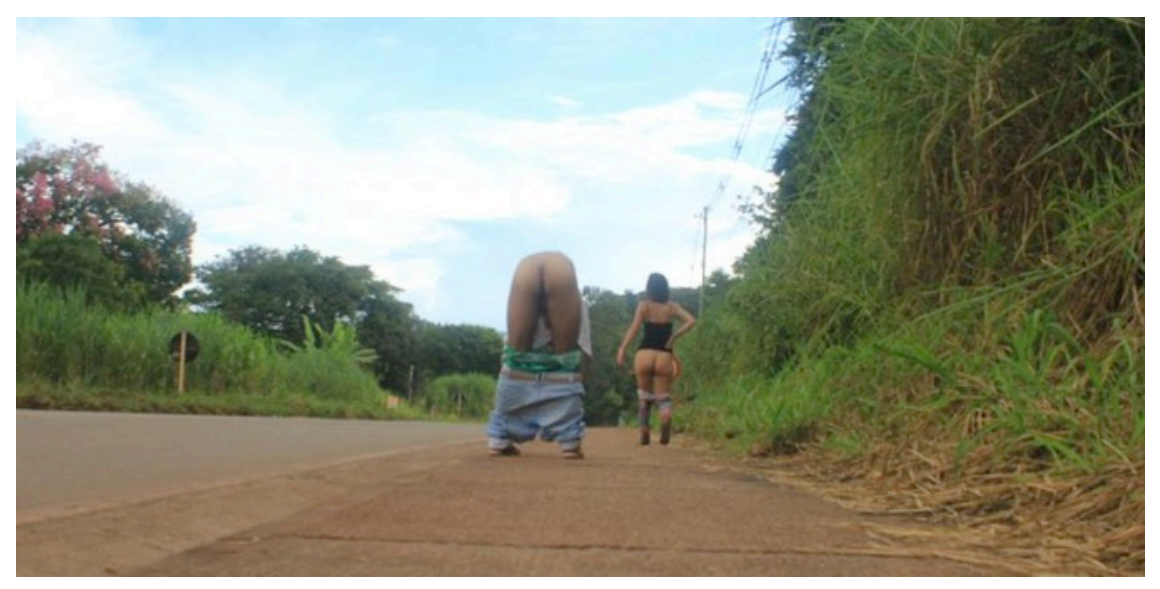

26.

"O que você pode realizar por meio de uma escultura não precisa ser construído como um prédio; o que pode ser feito na pintura não precisa ser cinzelado como uma escultura; o que pode ser feito em desenho não precisa ser feito à óleo como a pintura; o que se pode realizar com um pedaço de papel não precisa ser a lápis como um desenho; e o que você consegue obter na sua cabeça não precisa nem de um pedaço de papel" (TOMAS SCHIMIT, ad tempura)

"O nivel que a ciência alcançou é determinado pela medida em que é capaz de uma crise de seus conceitos básicos" (HEIDEGGER) in (DANTO, 2009 p. 73)

Deliberar: resolver pós exame ou discussão.

Se resolve algo ambíguo? 
Performance: tencionar limites.

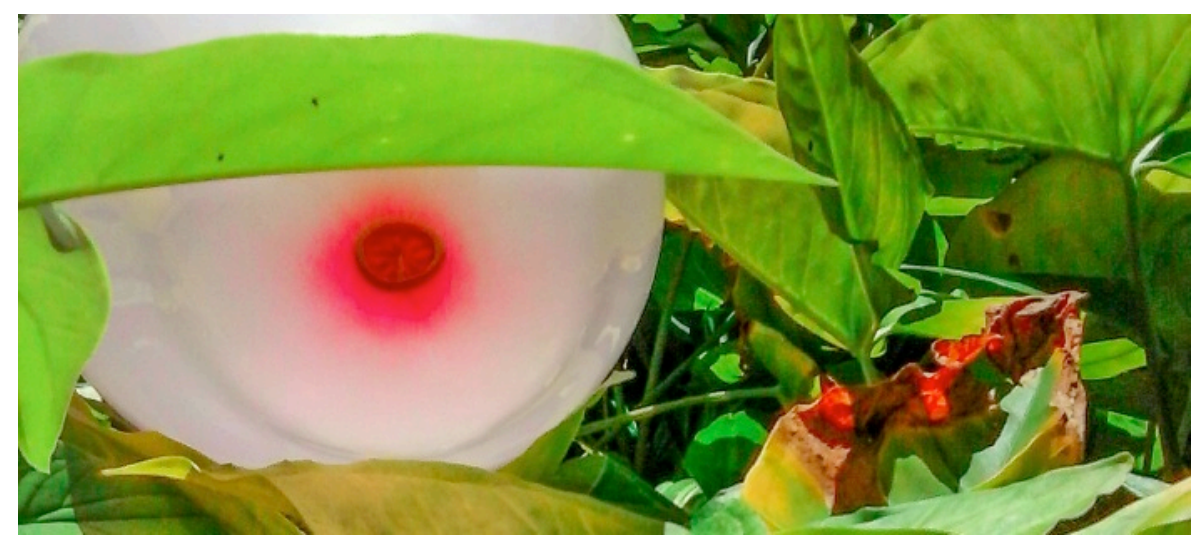

27.

Criptografar: dar um tiro que a bala vai para o lado oposto.

Perplexo: do latim Perplexu, 'emaranhado' e daí indeciso. Duvidoso, hesitante, irresoluto. Numa eterna flutuação (...)

Se faz uma arte impura, que contenha uma mistura de qualquer outro meio: reflexo com a arte mesclada que não é realmente pintura, escultura, fotografia, instalação ou mesmo arte.

Indeciso/estagnação: "As potencialidades criativas são enormes, mas os esforços parecem mingalar, justamente quando são propostas posições radicais, posições radicais não significam posições estéticas, mas posições globais vida-mundo. " (OITICICA, Brasil Diarreia, 1973)

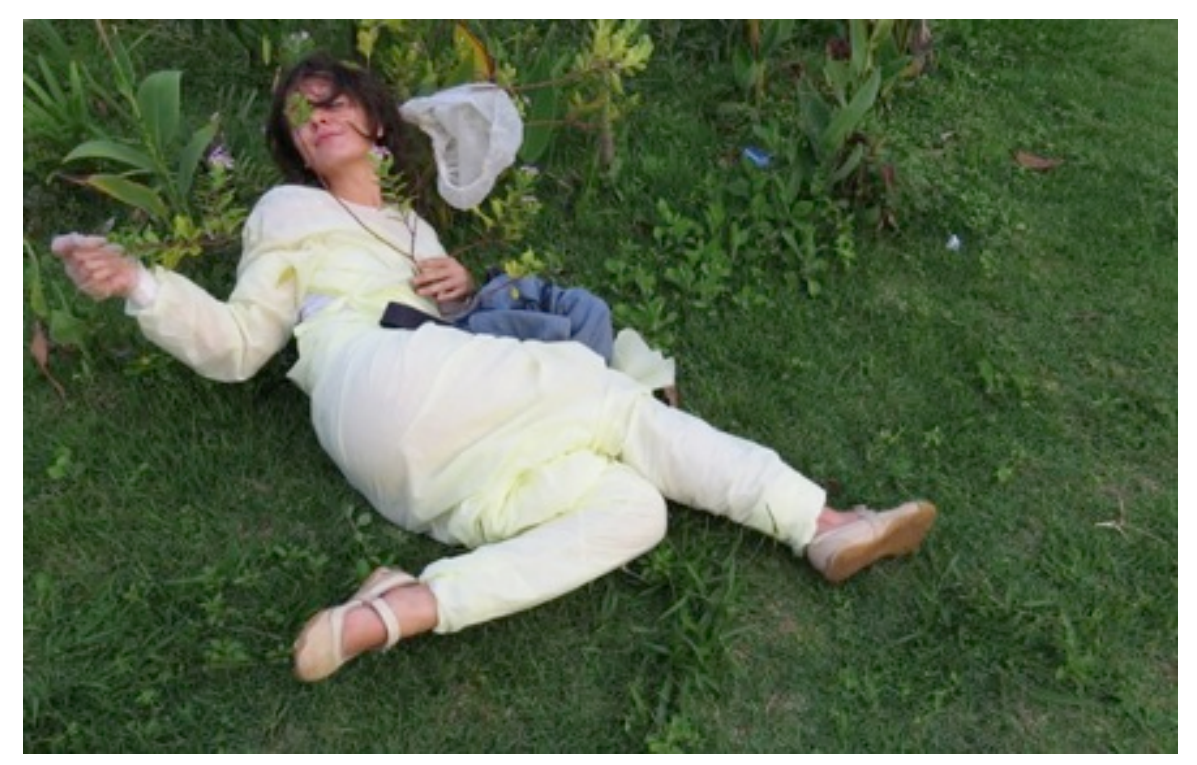

28.

Coeficiente de arte: a diferença entre a intenção e a sua realização, uma diferença de que 0 artista não tem consciência.

DELEUZE: A grama está no meio, nem em cima ou embaixo.

"No entremeio se experimenta essa subjetividade radical que dá impulso a lógicas desconhecidas de cada um. Assim se conhece o prazer de sentir seu

corpo vivo."

(ONFREY, 2009, p.38)

O propósito fica no meio do caminho posição indireta $=$ a favor da mistura 


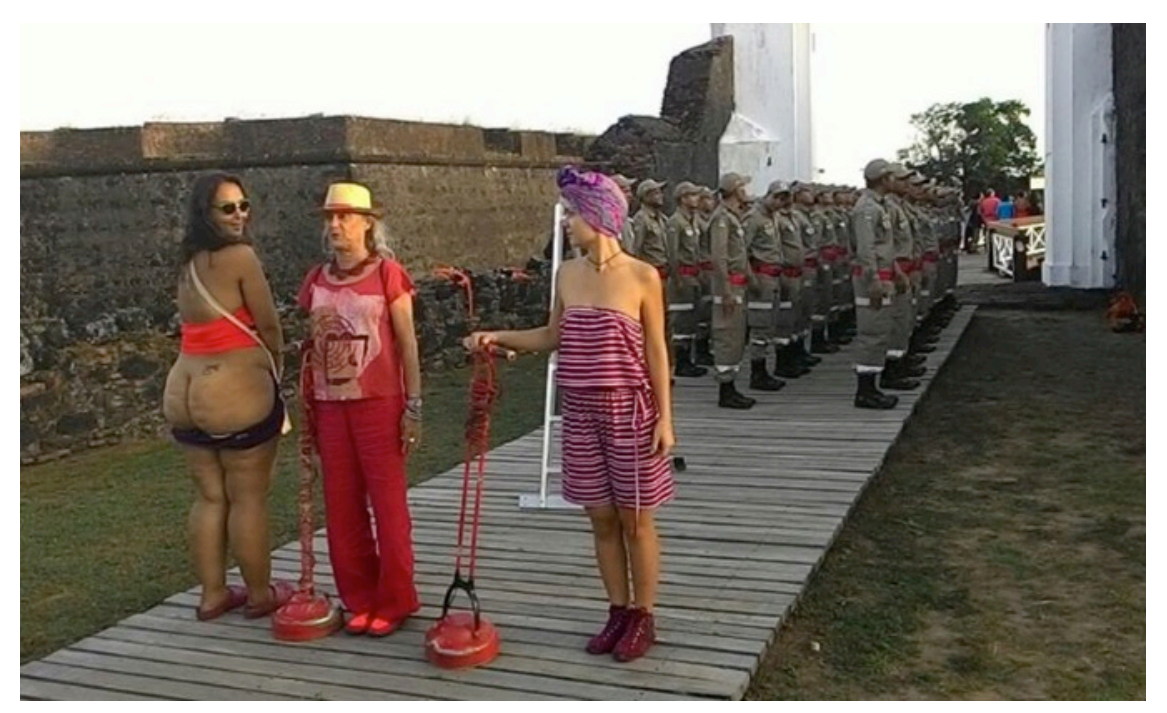

29.

Nem contra, nem a favor. Uma dupla escolha ou não escolha. Produzir ambiguidade entre função utilitária/ estética.

Oscilação entre contemplação e uso.

"Não existe pois o problema se arte é isso ou aquilo ou deixa de ser

- não há definição do que seja arte" (OITICICA, Posição e Programa, 1966)

Trocadilhos: jogar com palavras confundindo com uma variedade de sentidos e de nonsenses, achando graça nas indecisas associações.

(...) também tem os trocadalhos do carilho
Distribuição das posições: transformar o termo 'bom' em 'ruim' e viceversa, sem mudar o funcionamento da própria oposição. Seria mudar os sentidos e confundir. Interessa captar as lexias disléxicas.

"Expressões de duplo sentido agem na determinação da estrutura comum da significação, mas a significação é considerada na sua ambiguidade, e a interpretação a inteligência das significações múltiplas."

(MAGALHÃES, 1980, p.30)

Momento de passagem da crise de valores, dos posicionamentos antagônicos.

A questão é o seu ultapassamento, diluição dos opostos, a superação da crise, a cicatriz.

Empatia: Tentar entender o outro por meio da culpa ou uma separação.

Identificação: Sensação de semelhança, mistura, redenção. 


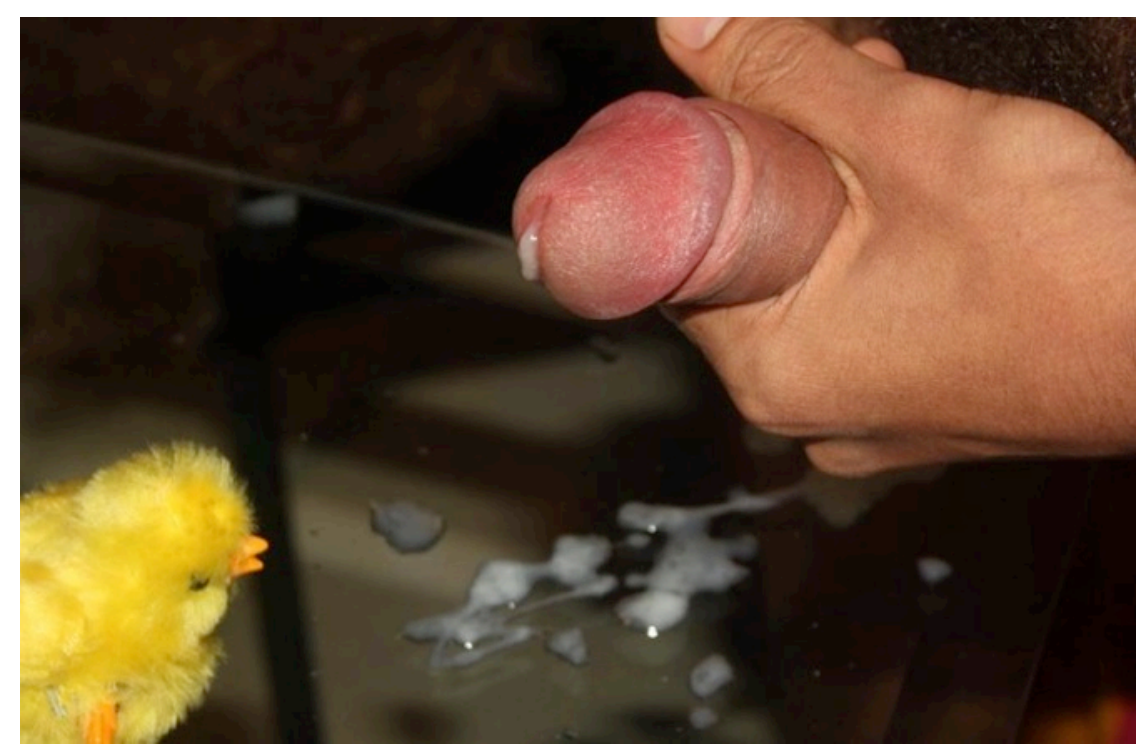

30.

"Esse mundo intermediário obedece às próprias leis que ignoram as que regem as relações humanas habituais"

(ONFRAY, 2009, p.36)

lugar de extraterritorialidade: não governado.

Partilha do sensível: comum partilhado e partes exclusivas.

Tomar parte do tempo/espaço.

Luísa, é isso mesmo?
"A experiência errática afirma-se como uma possibilidade de experiência urbana, uma possibilidade de crítica, resistência ou insurgência."

$$
\text { (JACQUES, 2012, p.19) }
$$

Insurgência: rebelar-se, insubordinar-se ou resistir pelas brechas.

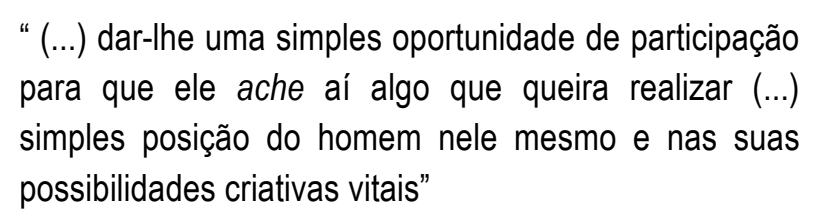
possibilidades criativas vitais"

(OITICICA, Posição e programa, 1966)

Vontade de potência: querer poder é diferente de exercício de domínio. Querer-se através da vontade é diferente da vontade de querer potência. Se pede por pluralidade de forças que se afirmam como antagônicas. A força se relaciona com as outras sem negá-las, mas afirmando sua diferença. A potência está na vontade: elemento diferencial. A vontade de potência como criadora.

\section{Um risco suja e preenche o vazio}

\section{0 vazio têm liberdade quando ninguém vê.}

Hummm! Quer dizer que só é possível ser livre quando ninguém está olhando.

Pouco. Triste. Quase. 

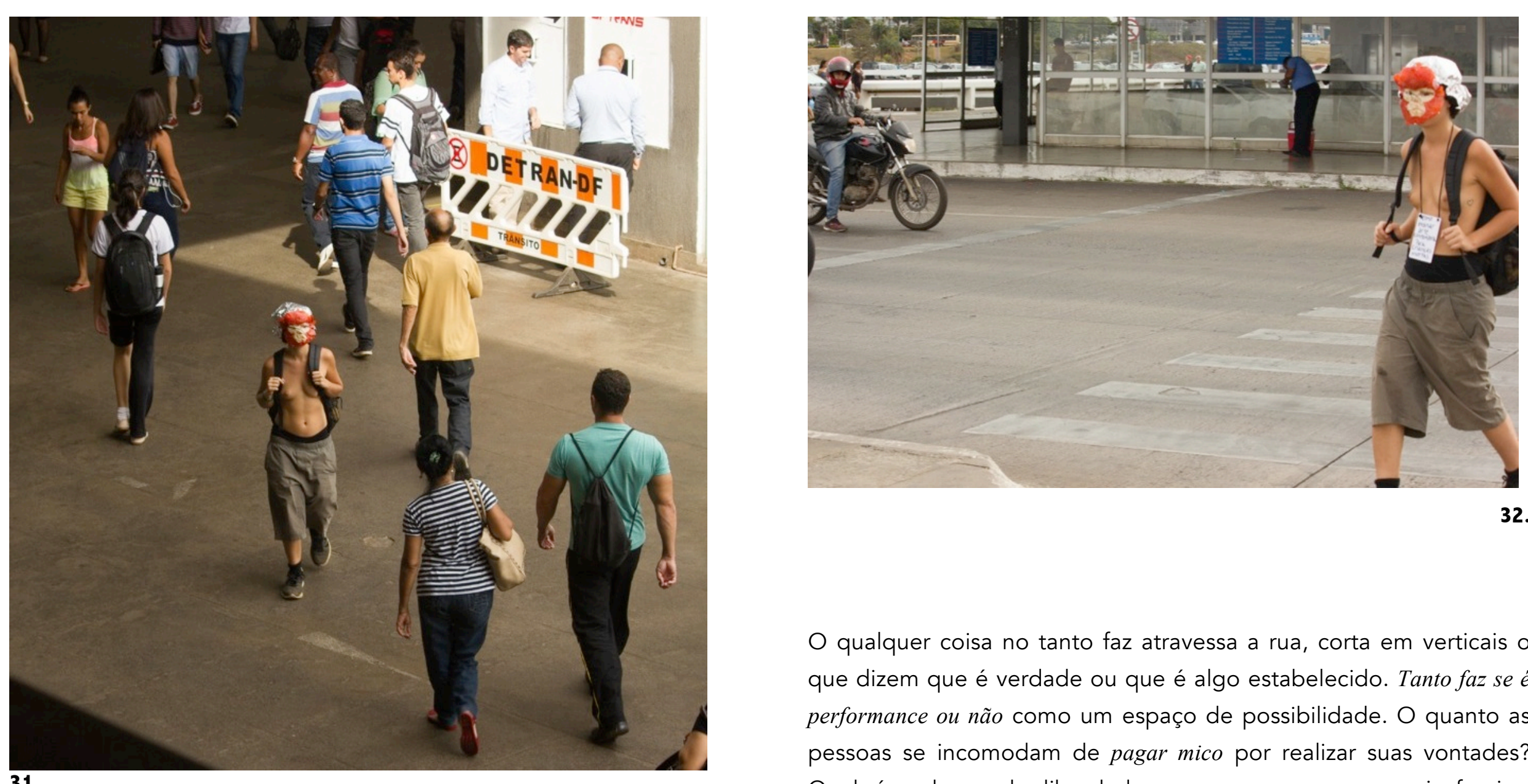

32.

31.

O qualquer coisa no tanto faz atravessa a rua, corta em verticais o que dizem que é verdade ou que é algo estabelecido. Tanto faz se é performance ou não como um espaço de possibilidade. $\bigcirc$ quanto as pessoas se incomodam de pagar mico por realizar suas vontades? Qual é o lugar de liberdade para exercer suas esquizofrenias, dislexismos, criancices, arbitrariedades, absurdos e anomalias do corpo escondido (corpo que não se vê por não encaixar no padrão midiático ou corpo desafiado à violência da cultura de machismo). A arte como um micro-poder político: expressão autêntica sobre o controle civil e 0 Estado; transparente vontade de poder. 


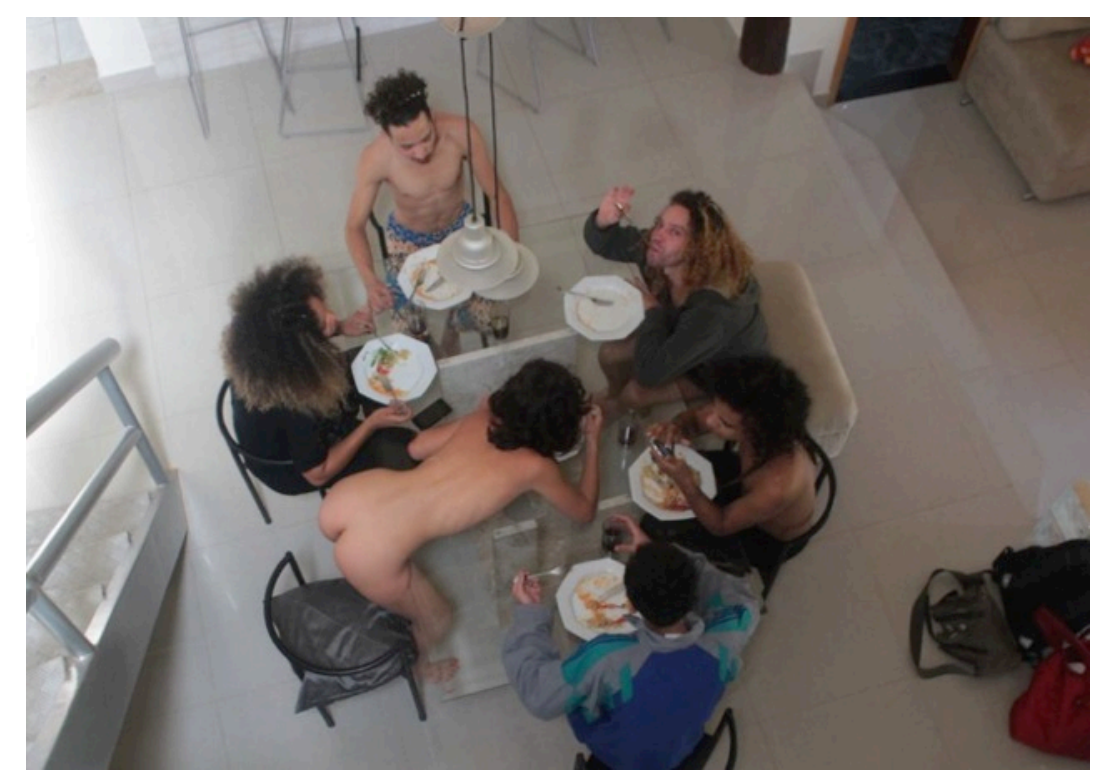

33.

"Pode alguém fazer obras que não sejam obras de arte?" (DUCHAMP, 1913. Nota) in (TOMKINS, 2013, p. 14)

A arte como qualquer coisa, ou nada.

llegalidade ante a normalidade comum embate ou simbiose.

Ser livre em seu abandono, inventar sua própria vida. Liberdade que se funda numa falta de ser, no nada: desengajamento niilista.

Quando nada é, tudo pode ser.

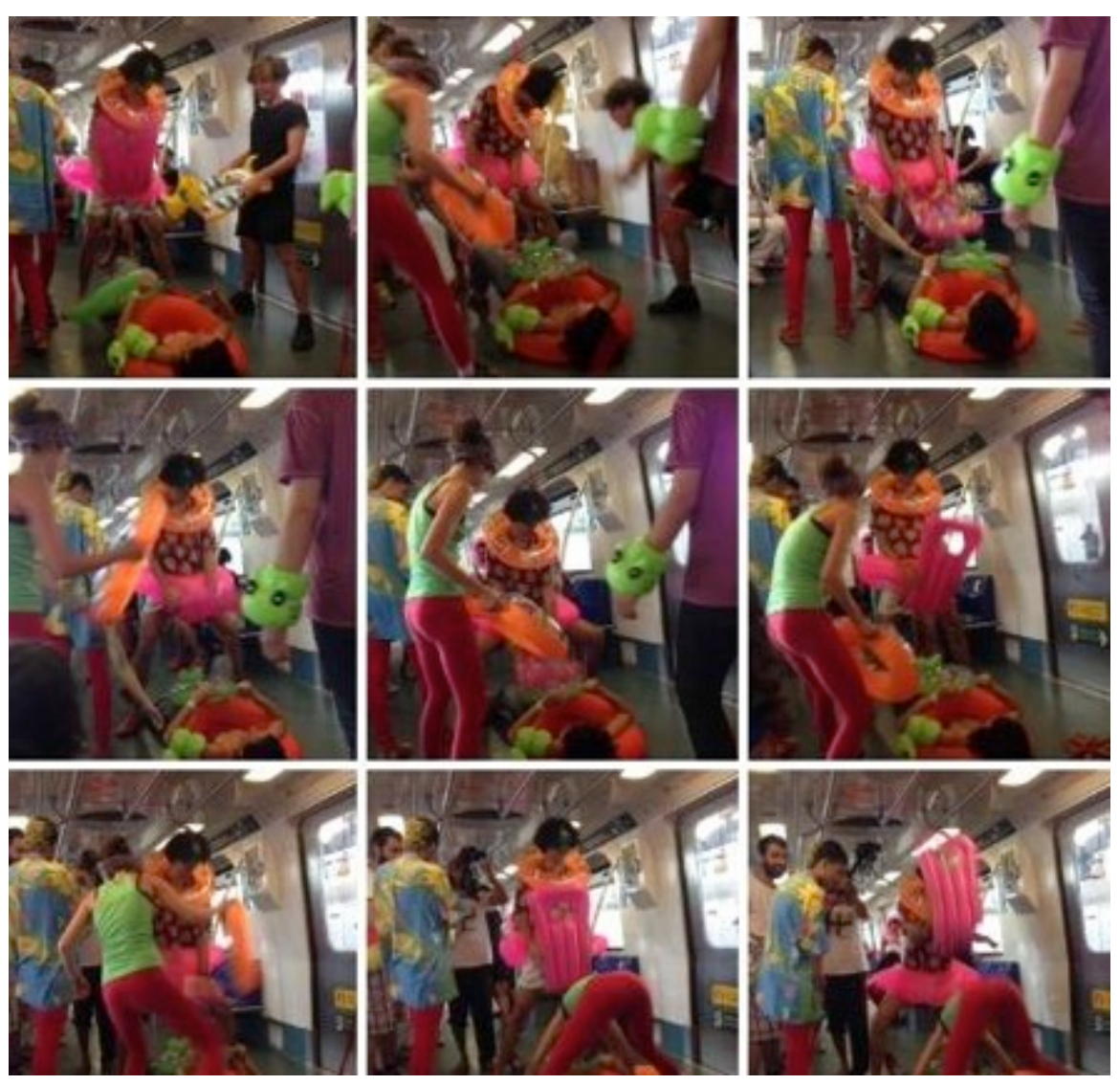

34.

Uma emancipação não é pela formação de uma nova verdade, mas pela própria dissolução da própria noção de verdade e da criação de novas fábulas (a verdade que se pluraliza) que não se afundam em nada, sem validade legítima, nada de aprofundamentos, apenas superfícies deslizantes. 


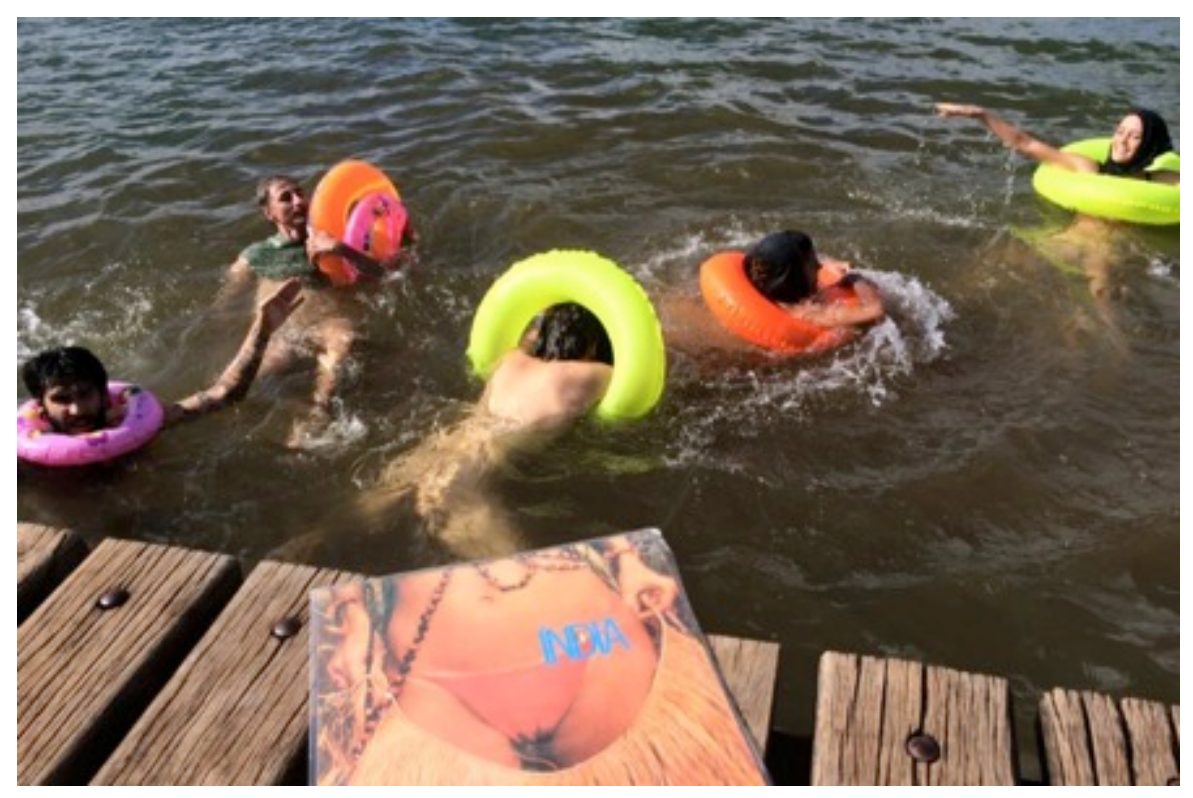

35.

Interpretar: imposição da existência.

Um intérprete percebe uma ideia e interpreta.

O espaço de possibilidade - alguma coisa para dar passagem

"A proposição é uma consequência

do principio da arte como uma configuração da vontade de poder".

(HEIDEGGER, 1889, p.12)
Édem: Campus experimental onde toda experiência é permitida.

"É para esse espaço selvagem da paisagem que projetamos medo e o desejo de nela fundir-se; é para lá que novamente voltamos nosso olhar a fim de observar as coisas que cabem no horizonte do infinito marítimo ou no céu estrelado - ou ainda, se estivermos disponíveis, numa dança prosaica com as coisas que estão sobre este mesmo chão (...) Na coreografia podese com facilidade inverter as relações de poder e de escala - acionar os dispositivos de desejo."

$$
\text { (TAMAYO, 2014, p.217) }
$$

Liberdade: existência desvinculada da determinação.

"O ponto em comum entre todos os objetos que classificamos como 'obra de arte' reside em sua faculdade de produzir o sentido da existência humana (de indicar trajetórias possíveis) dentro desse caos que é a realidade. E é em nome dessa definição que a arte contemporânea -em bloco- é hoje desacreditada, geralmente por aqueles que veem no conceito de 'sentido' uma noção preexistente à ação humana. "

(BOURRIAUD, 2009, p.74)

Um ignorante pode ensinar a outro ignorante aquele que ele mesmo não sabe. (RANCIĖRE, 2012, p. 7) 
Sublime (Kant): fazer da arte um testemunho do encontro com o irrepresentável que desconcerta todo o pensamento.

As coisas não têm sentido inerente colado a elas.

Absurdo: desrazão de mundo.

Um espaço comum pode ser visto como irreconhecível; sensação de novo ao banal.

\section{Pensamento em abismo: desastre do seu não reconhecimento:} paisagem sem objetivo.

O impossível que aceita a indeterminação e o transitório.

\section{Pensamento fraco: oposição ao pensamento absoluto. A verdade absoluta} não pode ser conhecida (religião, verdades, evidências, senso comum). A certeza como um envolvimento, uma capa de um espaço - resto de que se acredita.

Deixar as afirmações em suspensão, já que não é possível responder as questões.

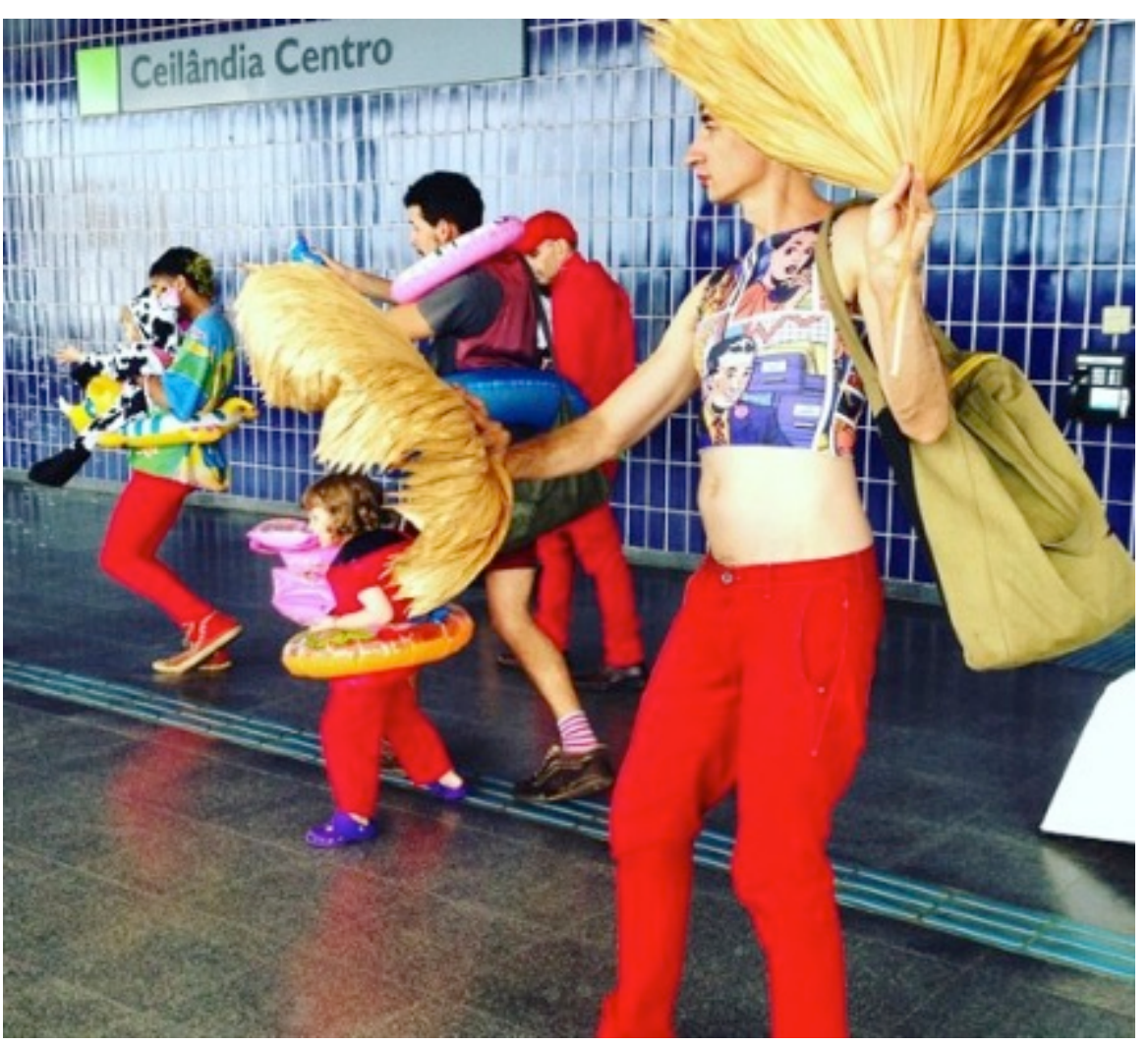

36.

"É somente uma questão de conseguir deixar de ver a coisa como um quadro - de fazer um 'atraso' dela no modo mais geral possível, recorrendo não tanto aos diferentes sentidos em que se pode entender a palavra 'atraso', mas a totalidade deles

com sua carga de indecisão".

(DUCHAMP) in (TOMKINS, 2013, p. 11 -rodapé) 
"Hans Belting registrou o fato de que a arte não parecia mais ter a possibilidade de uma progressiva desenvolvimentista. Como poderia haver uma História da Arte do presente se essa condição objetiva falhasse? (...) Ter uma História dá sinais que ele tinha e mantinha um padrão estético (...) O seu problema está em conceber a História de algo que carece de uma história adequada"

$$
\text { (DANTO, 2009, p.70) }
$$

"A experiência é, nesse sentido, fissura, não saber, prova do desconhecido, ausência de projeto, errância nas trevas (Bataille)"

(GIORGIO AGAMBEN) in (TAMAYO, 2014, p. 217)

\section{desprovido de sentido $=$ originalmente livre?}

Informal: Pessoa descontraída, que não segue regras rígidas. Palavra usada para descrever situações onde há cumplicidade, confiança ou familiaridade. Pode indicar uma forma de se vestir. A linguagem informal é um tipo de linguagem usada em alguns contextos quando existe confiança entre os interlocutores, sendo bastante comum entre amigos e familiares. Trabalho informal é a designação dada a um tipo de trabalho em que não existe um acordo escrito como um contrato, este é 0 caso de algumas pessoas que trabalham como camelô. 0 informal não cumpre forma definida, conhecida ou determinada.

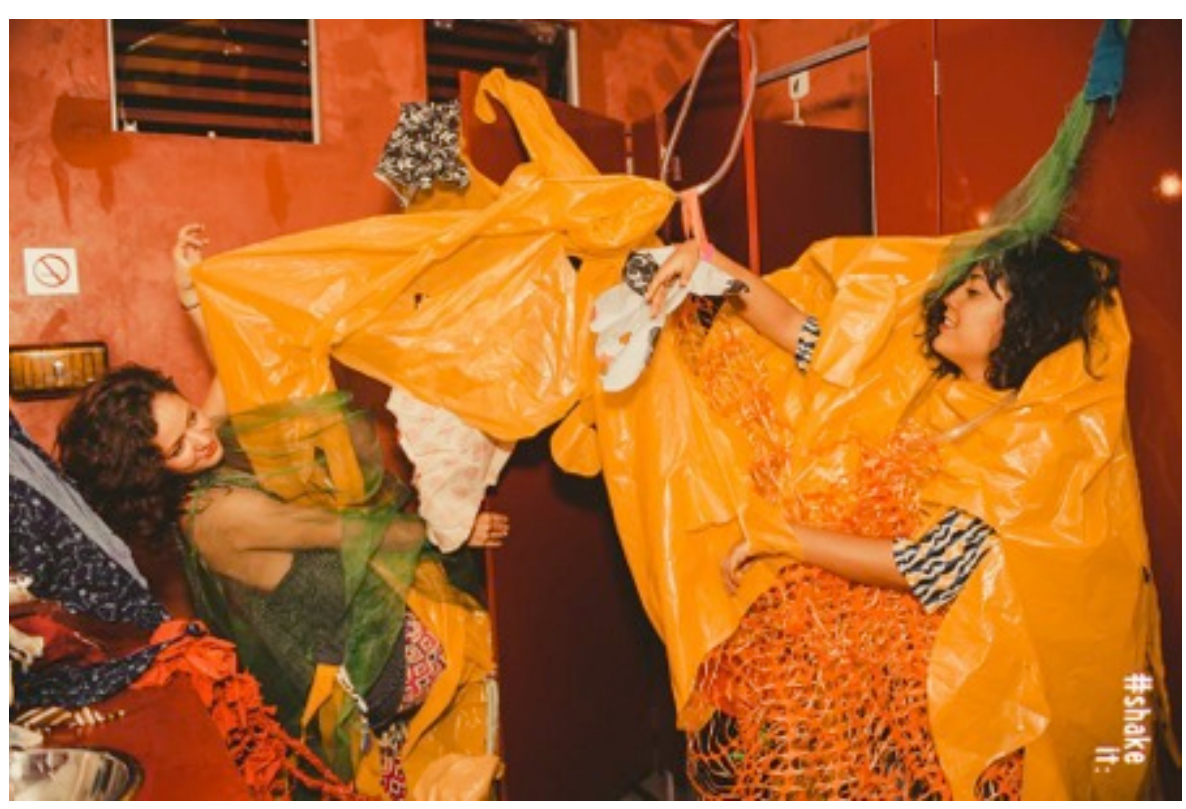

37.

O infinito é aquilo que não sabemos.

Fazer uma coisa sem determinar um fim

Zaratustra: abolir o mundo aparente não significa eliminá-lo, tampouco inverter a posição, não é substituir o mundo ideal (e valores) pelo mundo sensível. Trata-se de dissolver - em nome de um além - de algo totalmente outro.

Experimentação científica do tolo: desvendar o enigma; valoração do processo para além do saber. 


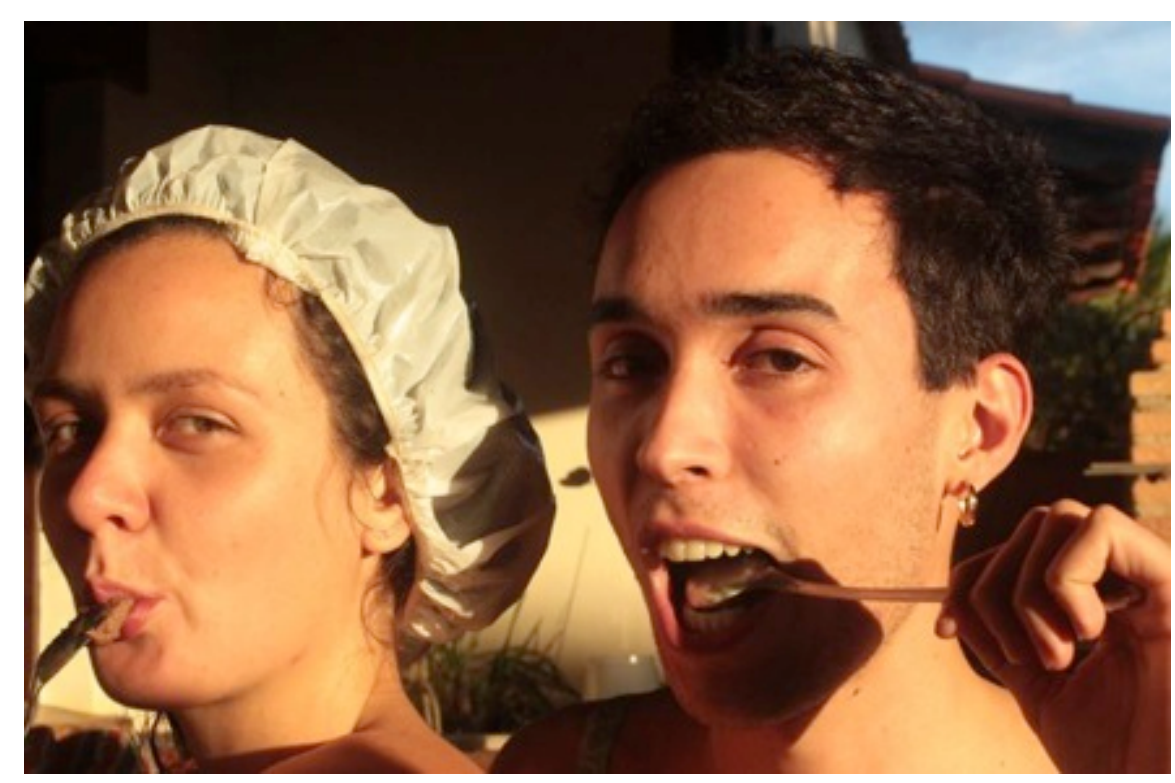

38.

\section{desconhecido: risco}

ou ao contrário

Existência artística: esforço conjunto do artista + espectador + intervenção imprevisível do acaso. Criação livre pela própria natureza - por não estar sujeita às limitações de controles pessoais.

"Torna-se necessário renunciar definitivamente ao phatos da verdade, as promessas consoladoras do mundo verdadeiro e afundar em um universo cômico, farsesco e criador, no qual tudo é máscara".

$$
\text { (PECORARO, 2007, p. 21) }
$$

"Para mim, intelecto é uma palavra seca demais. Gosto da palavra 'crença'. Geralmente julgo as pessoas dizem 'eu sei', elas não sabem, elas acreditam (...) A arte é uma forma de fugir para regiões não governadas pelo espaço e tempo. Viver é acreditar.

Essa é a minha crença".

(DUCHAMP) in (TOMKINS, 2013, p. 437)

Dar um dar sentido desprovido de todo sentido

\section{Ultrapassamos o niilismo ao ver sentido no absurdo}

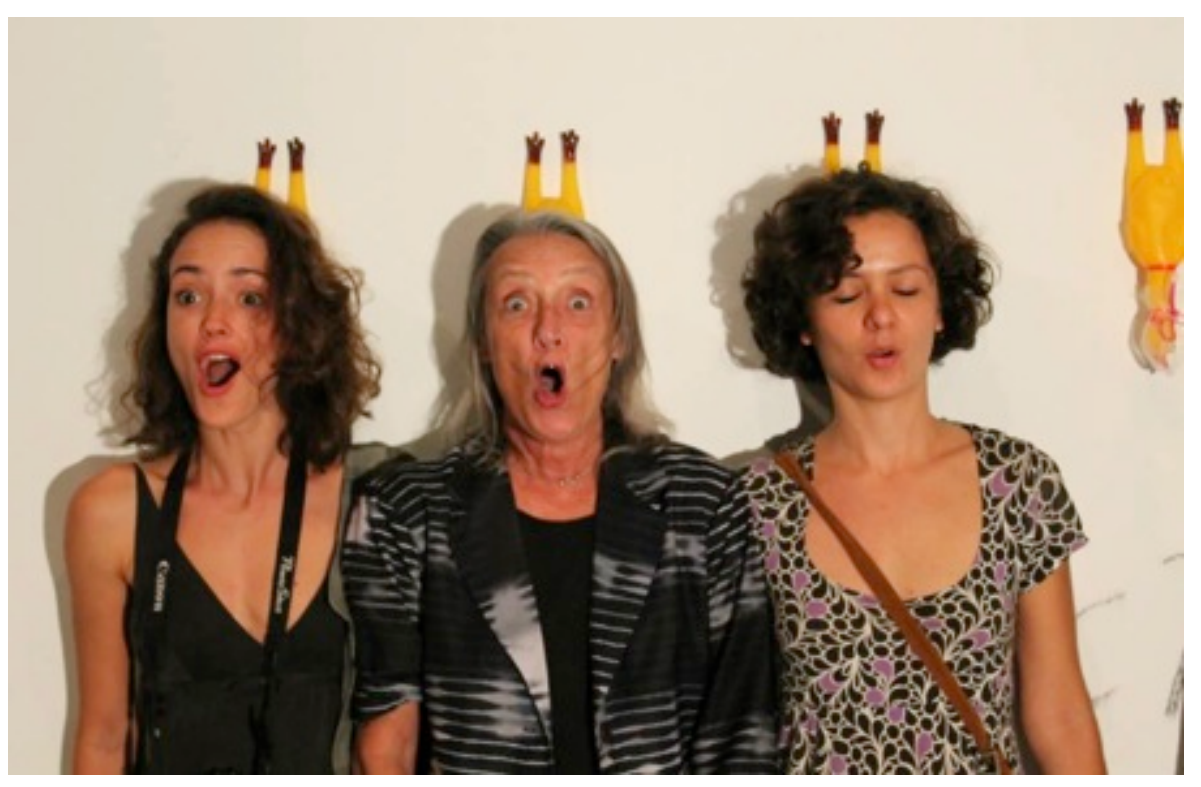

39. 


\section{(in)CONCLUSÃO}

As coisas podem ser criadas do nada, aniquiladas no nada, como também feitas para nada. A im-posição do nada vem da ideia de que não há conhecimento de nada em absoluto; uma prática niilista de que se nada tem, tudo pode ser construído. Não seria transformar algo em nada, mas desvelar o visto, abandonar algo imposto e abrir espaço de indeterminações, flutuações ou novos começos. 0 abandono dos sentidos e delimitações vem como potência e pulsão para metas desconhecidas: o ponto zero para começar e perceber a chegada de fenômenos novos. Considera-se o nada como primeiro ponto de partida para a obra, o nado no lugar em que não se sabe e não se entende, este como percepção vazia do espaço e corpo que nasce em seu avesso. O niilismo surge em contextos decadentes, de crise, enquanto esta oficina surge dos lugares abandonados, do vazio da cidade, do olhar obtuso e do entremeio não governado que supera as dicotomias rindo delas. $\mathrm{O}$ conceito de arte exige abertura, exige possibilidade de se ajustar ao surgimento de situações não previstas, a situações que independem de qualquer tipo de regra ou restrição. $O$ fechamento deste conceito é o mesmo que excluir as condições de criatividade da arte e suas licenças poéticas. Que tenhamos aqui essa licença para exercer a vontade de poder, a vontade de ser e de não ser: independente de correntes dominadoras. $\mathrm{O}$ que se pode na arte? $\mathrm{O}$ quanto se possibilita? Aqui desaparece a formalidade de defender uma ideia conjunta e pertinente, uma vez que o conjunto da pesquisa aparece em citações soltas e frases errantes que caminham sem linearidade, mas de maneira rizomática. Estes soltos, dançam entre si numa coreografia dispersa: nado ou nada sincronizado.

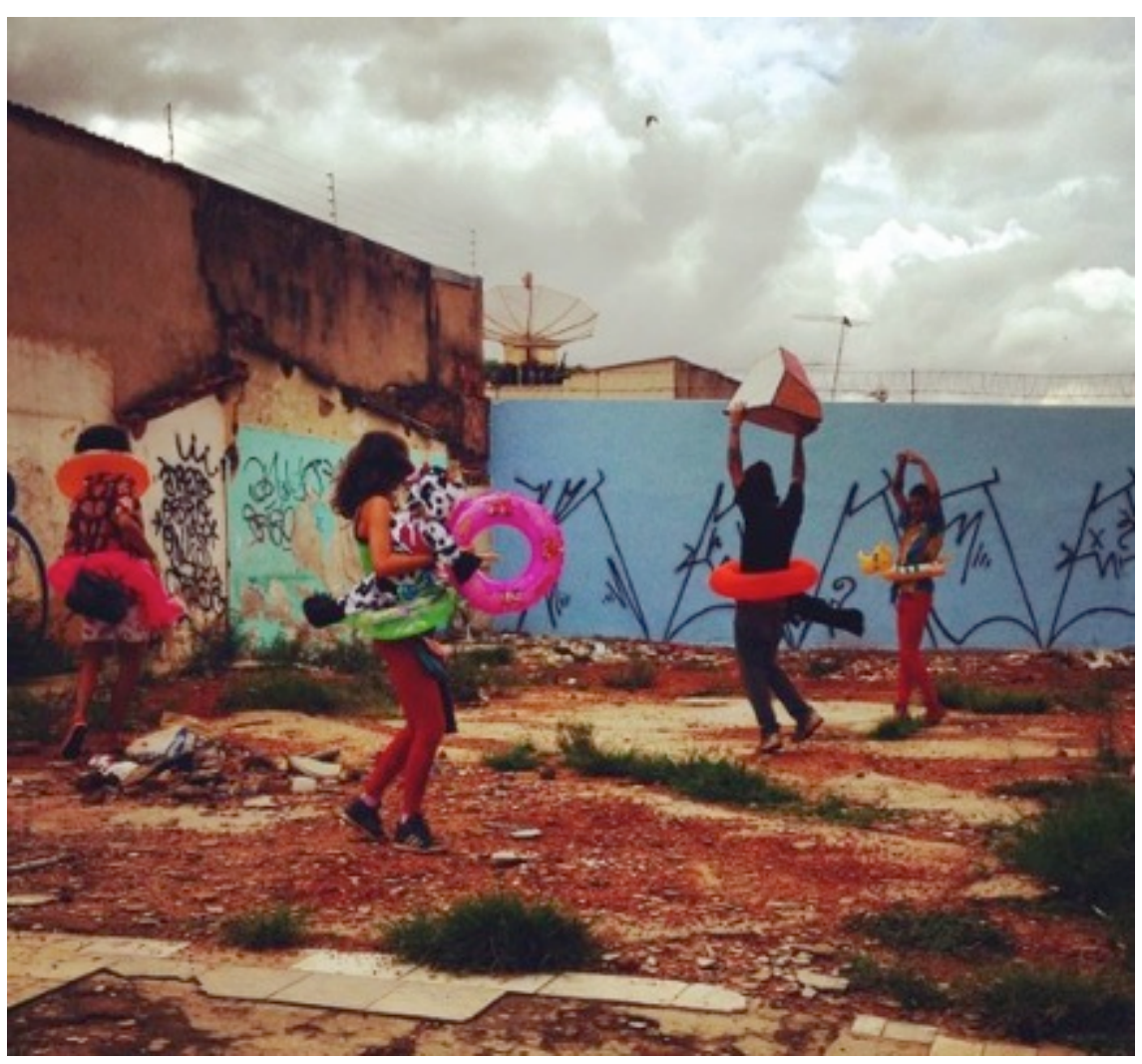

40. 


\section{LISTA IMAGENS}

\section{Nado no Nada.}

Da série: Oficina de Niilismo. Proposta por Natasha de Albuquerque para Corpos Informáticos. Fuleragem Coletiva. Foto: Corpos Informáticos. Performance Corpo Política. Brasília, 2015.

\section{Balé de Boias em Método Scanning.}

Da série: Oficina de Niilismo. Por José Mário Peixoto (Zmário) para transeuntes. Fuleragem Coletiva. Foto: Corpos Informáticos. Performance Corpo Política. Brasília, 2015.

\section{Aprecio de Bananas.}

Da série: Como Observar Arte Contemporânea. Foto-performance em Autorretrato. Brasília, 2016.

\section{Pintos.}

Da série: Relação Erótica com as Coisas. Frame do vídeo. Registro: Corpos Informáticos. Exposição birutas(E)vento. Brasília, 2014.

\section{Corpos Informáticos.}

Registro dos bastidores para performance na peça ULTRA Romântico do grupo Liquitificador. Tanto faz se é performance ou não. Corpos Informáticos: Mariana Brites, Ingrid Abstrata, Tiago Marques, João Stoppa, Romulo Barros, Natasha de Albuquerque, Mateus Carvalho Costa, Matheus Opa, Bia Medeiros, Ayla Gresta, Maria Eugênia Matricard, Zmário, Gustavo Sivamaral, Bruno Corte Leal. Foto: Liquitificador. Brasília, 2016.

\section{Queimada de Sutiãs.}

Jogo de queimada para mulheres de sutiã. Movimento Político. Proposta por Andaime Cia de Teatro. Foto: Andaime Cia de Teatro. Dia internacional da Mulher. Esplanada, Brasília, 2016.

7. UTI: Urbanóides Transitam o Inexistente.

Performance. Proposta por Corpos Informáticos: Zmário, Ayla Gresta, Rômulo Barros, Mariana Brites, Bia Medeiros, Natasha de Albuquerque, João Stoppa. Dia sem evento. Praça do Relógio, Taguatinga, 2015.

\section{Avesso Avesso Avesso.}

Fotografia. Proposta por Natasha de Albuquerque. Foto: Rafael Godoy Brito. Brasília, 2013.

\section{Tanto faz se é performance ou não.}

Da série: Oficina de Niilismo. Proposta por Natasha de Albuquerque para família Günther. Foto: Ary Coelho. Brasília, 2015.

\section{Nádegas a declarar.}

Da série: Miss Universo. Fotografia. Proposta por Natasha de Albuquerque. Foto: Matheus K. Opa. Pirenópolis, 2016.

\section{Miss Universo.}

Fotografia. Proposta por Natasha de Albuquerque. Foto: Matheus K. Opa. Pirenópolis, 2016.

\section{Eu me inspiro em Fluxus e Fluxus não se inspira em mim}

Foto para artigo "Fluxus: Estado indeterminado, flutuante". Inédito. Brasília, 2015.

\section{Parangolé.}

Proposta por Hélio Oiticica e Natasha de Albuquerque. Foto: Rafael Godoy Brito. Moreré, 2011.

\section{Oficina de Nudismo.}

Proposta por Natasha de Albuquerque para Vanderlei Costa e público. Foto: anônimo. II Gran Salão Promíscuo: A Favor da Mistura. Brasília, 2016.

\section{Pode Pegar.}

15 caixas de chiclete mastigado. Proposta iterativa de Natasha de Albuquerque para público. Foto: Kael Studart. I Gran Salão Promíscuo. Brasília, 2015.

\section{MogAmAMEX: Mognos Amazônicos em Extinção para passear.} Proposta por Corpos Informáticos. Foto: Natasha de Albuquerque. Brasília, 2016.

\section{Adoro banheiros.}

Foto-performance em Autorretrato. Brasília, 2015. 
18. Invasão de construção abandona.

Por Natasha de Albuquerque e Ana Flávia Silvestre. Brasília, 2015.

19. Desobediência civil.

Por Mariana Brites. Foto: Alexandra Martins.

\section{Nado no Nada.}

Da Série: Oficina de Niilismo. Por Ana Flávia Silvestre. Foto: Natasha de Albuquerque. Piscina de Ondas desativada. Brasília, 2016.

\section{Talvez se.}

Fotografia. Por Natasha de Albuquerque. Brasília, 2013.

\section{Anticorpos.}

Perfomance e instalação. Por Corpos Informáticos. Registro: Corpos Informáticos. Exposição A-PLAY. Galeria ECCO, Brasília, 2014.

\section{Oficina de Nudismo.}

Instalação. Por Natasha de Albuquerque. Foto: Bruno Corte Leal. Exposição Transitório Permanente. Galeria Elefante, Brasília, 2016.

24. Navegar: registro a deriva de sentido.

Por Natasha de Albuquerque. Santiago, 2014.

\section{Eu Como Você.}

Identificação de um livro achado ao acaso e ao gosto pessoal. Por Natasha de Albuquerque. Foto: Gustavo Sivamaral e Romulo Barros. LlolaLab Brechó e Peluqueria. Brasília, 2015.

\section{Expulsos de Inhotim a caminho de Brumadinho}

Por Natasha de Albuquerque e Rômulo Barros. Autorretrato. Lugar de extraterritorialidade, 2014.

\section{Imagem de divulgação para Oficina de Nudismo.}

Acaso entre aulas. Por Natasha de Albuquerque e Camila Cidreira. Universidade de Brasília, 2015.

\section{Tash e mar(ias-sem-ver)gonhas.}

Encontro duradouro durante a performance UTI: Urbanóides Transitam o Inexistente. Por Corpos Informáticos. Foto: Corpos Informáticos. Praça do Relógio, Taguatinga, 2015.

\section{Encerando formalidades.}

Da série: Encerando a chuva. Iteração da formatura de bombeiros durante o evento de performance Corpus Urbis. Por Corpos Informáticos. Foto: Raphael Couto. Macapá, 2015.

30. Pinto ao Pinto: Uma Questão de Identificação.

Da série: Relação Erótica com as Coisas. Por Jaja Rolim e Natasha de Albuquerque. Foto: Natasha de Albuquerque. Brasília, 2015.

\section{Ninguém.}

Da série: Dizem que ninguém é perfeito. Por Natasha de Albuquerque. Foto: Ana Flávia Silvestre. Apoio moral: Fernando Carvalho. Rodoviária do Plano Piloto, Brasília, 2016.

\section{Ninguém.}

Da série: Dizem que ninguém é perfeito. Por Natasha de Albuquerque. Foto: Ana Flávia Silvestre. Apoio moral: Fernando Carvalho. Rodoviária do Plano Piloto, Brasília, 2016.

33. Bela Recatada e do Lar.

Da série: Com Tradições de um Almoço sem Relva. Simples almoço entre amig(x)s. Foto: Jaja Rolim. Brasília, 2015.

34. Nadx: sem distinções.

Da série: Oficina de Nudismo. Proposta por Natasha de Albuquerque para Corpos Informáticos. Foto: Luisa Günther. Performance Corpo Política. Brasília, 2015.

35. Nado Onde as Nádegas Estão em Evidência: sem distinções.

Da série: Oficina de Nudismo. Proposta por Natasha de Albuquerque para Corpos Informáticos. Junto à série: Levando os LPS de Gal Para Passear. Proposta Por Arthur Scovino. Foto: Arthur Scovino. Performance Corpo Política. Brasília, 2015.

36. Mistura, indistinção.

Por Vanderlei Costa e dispersos. Foto: Luisa Günther. Performance Corpo Política. Brasília, 2015. 


\section{Parangolé Coletivo}

Proposta por Natasha de Albuquerque para Festa FACTORY. Foto: Pedro Lacerda. Usina Artes e Entretenimento. Brasília, 2016.

38. Eu Como Você: Identificação entre amigas.

Por Natasha de Albuquerque e Pole Bilau. Foto: Loucas Figueiras. Brasília, 2015.

39. Instalação Sonora.

Galinhas ao prego com possibilidade de iteração. Proposta por Corpos Informáticos. Na foto: Ayla Gresta, Bia Medeiros e Natasha de Albuquerque. Foto: Corpos Informáticos. Exposição birutas(E)vento. Galeria Espaço Piloto. Brasília, 2014

\section{Ao-bando-nada.}

Da série: Oficina de Niilismo. Proposta por Natasha de Albuquerque para Corpos Informáticos. Na foto: João Stoppa, Ayla Gresta, Flora Nunes, Diego Torres e Rômulo Barros. Registro: Luisa Günther. Performance Corpo Política. Brasília, 2015.

\section{REFERÊNCIAS BIBLIOGRÁFICAS}

ALBUQUERQUE, Natasha de; MEDEIROS, Maria Beatriz de. Composição urbana: surpreensão e fuleragem. Rio de Janeiro: $S E S C$, 2013, p. 24 a 35.

BARROS, Manuel de. O livro sobre o nada. Ilustrações: Wega Nery. Rio de Janeiro/São Paulo: Record, 1996.

BATORÉO, Hanna Jakubowicz. Expressão do movimento em água (ACQUA-motion) no Português Europeu: Contribuição para tipologia lexical. Linguística. Rio de Janeiro. V.2, n.2, p. 171-191, dezembro de 2006.

BOURRIAUD, Nicolas. Estética relacional. Tradução Denise Bottmann. São Paulo: Martins Fontes, 2009.

CLARK, Lygia. Nós somos os propositores. In: Lygia Clark. RJ: Funarte, Coleção Arte Brasileira Contemporânea, 1980.

COHEN, Renato. Performance como Linguagem. São Paulo: Pespectiva, 2011.

COTTON, Charlotte. A Fotografia como arte contemporânea. Tradução: Maria Silva Mourão Netto. - São Paulo: Editora WMF Martins Fontes, 2010 .

DANTO, Arthur C. Após o fim da arte: A arte contemporânea e os limites da História: trad. Saulo Krieger. São Paulo: Odysseus Editora, 2006.

Hélio Oiticica. Org: Cesar Oiticica; VIEIRA, Ingrid. Rio de Janeiro: Beco do Azougue, 2009.

DELEUZE, Gilles. Francis Bacon: Lógica da Sensação. 
DELEUZE, Gilles; GUATTARI, Félix. Mil platôs- Capitalismo $\boldsymbol{e}$ esquizofrenia, vol.1. Rio de Janeiro: Editora 34,1995.

O que é filosofia? Tradução: Bento Prado Jr. E Alberto Alonso. Editora 34, São Paulo, 1992.

DUCHAMP, Marcel. O ato criador In: BATTCOCK, Gregory. A Nova Arte. São Paulo. Perspectiva: 2004.

FUREGATTI, Sylvia. Contribuições de Joseph Beuys para a base formativa da arte pública atual. 09/2012, Anais do Encontro Nacional da ANPAP (Online), Vol. 01, pp.686-701, Salvador, BA, Brasil, 2012

HEIDEGGER, Martin. Nietzsche, Vol I. Título original: Niettzsche Vol. 1, 1889. Tradução: Marco Antônio Casanova. 1. Ed. Rio de Janeiro: Editora Universitária, 2007.

Internacional Situacionista: deriva psicogeografia e urbanismo unitário. Org: Erahsto Felício. Porto Alegre: Deriva, 2007.

JACQUES, Paola Berenstein. Elogio aos errantes. Breve histórico das errâncias urbanas. Rio de Janeiro: EDUFBA. 2012.

MAGALHÃES. Ligia Cadermartori. A água: uma hermenêutica da imagem. Revistas eletrônicas PUCRS v.15, n.1. Universidade de Caxias do Sul, RS: 1980.

ONFRAY, Michel. Teoria da viagem: Poética da geografia. Tradução: Paulo Neves. - Porto Alegre, RS: L\&PM, 2009.

ORTHOF, Nina. Cosmos: Navegar; orientador: Karina Dias. Dissertação (Mestrado em Artes). Universidade de Brasília, Brasília, 2016.
O Que é Fluxux? O Que Nao é! O Porque/What's Fluxus? What's Not! Why. J Hendricks, E Salles, AC Danto - 2002 - Centro Cultural Banco do Brasil.

PECORARO, Rossano. Niilismo: passo a passo 77. Tradução: Jorge Zahar. - Rio de Janeiro: Zahar. 2007

RANCIÈRE, Jacques. O espectador emancipado; Tradução Ivone C. Benedetti.- São Paulo: Editora WMF Martins Fontes, 2012.

. A Partilha do Sensível. Tradução Mônica Costa Netto. -São Paulo: EXO experimental org.; Editora 34, 2009.

TADEU, Tomaz. A filosofia de Deleuze e o currículo. - Goiânia, Faculdade de Artes Visuais, 2004] 74 p. - (Coleção Desênredos; n.1)

TAMAYO, Yana. Paisagem cambiante: ensaio para um balé das coisas. 2014. 233 f., il. Dissertação (Doutorado em Artes)—Universidade de Brasília, Brasília, 2014.

THORNTON, Sarah. O que é um artista?: nos bastidores da arte contemporânea com Ai Weiwei, Marina Abramovic', Jeff Koons, Maurizio Cattelan e outros. -1.ed. - Rio de Janeiro: Zahar, 2015.

TOMKINS, Calvin. Duchamp: Uma Biografia; Tradução Maria Thereza de Rezende. São Paulo: Cosac Naify, 2013. 